\section{Endothelial vasomotor regulation in health and disease}

Norman R. Searle mDcm, Philippe Sahab mD
The purpose of this review is to provide the anaesthetists with a comprehensive update on the endothelial-cell control of local blood flow. This single cell layer was originally thought to represent only a passive barrier. It is now evident that it plays an active role in a broad variety of biological functions. Since the discovery of the endothelial-derived relaxing factor $(E D R F)$, it has been the subject of a considerable amount of research. It is established that EDRF is secreted continuously at a basal state and that many physical stimuli as well as vasoactive substances can modulate its secretion. Evidence presented indicates that the endogenous vasodilatation produced by EDRF is similar to that of the exogenous nitrovasodilator nitroglycerine and nitroprusside (i.e., nitric oxide). Aside from EDRF, the endothelium produces other vasodilating as well as vasoconstricting factors. $A$ review of the physiology of the endothelium regarding the local control of blood flow is provided along with its influence upon several pathophysiological states. Also included is an overview of the influence of anaesthetic agents on endothelial function. These findings linking vasomotor control to endothelial function will help to explain pathophysiological process and may lead to new therapeutic modalities.

Le but de cette revue de la littérature est de présenter une synthèse sur le rôle de l'endothélium dans la régulation du tonus vasculaire. Cette couche monocellulaire fut longtemps considérée comme une simple barrière diffusionnelle. Il est de plus en plus évident qu'elle joue un rôle très actif dans plusieurs fonctions biologiques. Depuis sa découverte, le facteur relaxant endothélial (EDRF), n'a cesse d'attirer l'attention des chercheurs. Présentement, on sait que l'EDRF est sécrété continuellement à l'état basal et que plusieurs stimuli physiques ainsi

\section{Key words}

ENDOTHELIUM; EDRF; NITRIC OXIDE.

From the Département d'Anesthésie-Réanimation, Institut de Cardiologie de Montréal, Montréal, Canada.

Address correspondence to: Dr. Norman R. Searle,

Département d'Anesthésie-Réanimation, Institut de

Cardiologie de Montréal, 5000 Bélanger est, Montréal,

Québec, Canada H1T 1 C8.

Accepted for publication 20th April, 1992. que des substances vasoactives peuvent moduler sa sécrétion. L'action de l'EDRF procède par la synthèse du même intermédiaire des nitrovasodilatateurs (i.e., l'oxyde nitrique). L'endothélium vasculaire ne sécrète pas uniquement l'EDRF. Il peut aussi synthétiser d'autres facteurs relaxants (prostacycline, facteur hyperpolarisant) ainsi que des facteurs vasoconstricteurs. L'interaction des agents anesthésiques sur la fonction endothéliale est discutée. Ces nouvelles découvertes sur le mécanisme du contrôle local vasomoteur reliées à l'endothélium permettront de mieux comprendre les processus pathophysiologiques et pos siblement nous aideront à développer de nouvelles modalités thérapeutiques permettant d'escompter des bénéfices cliniques.

\section{Contents}

Historical perspective of endothelium-derived relaxing factor (EDRF)

Biochemical action of EDRF

Physiological stimulants of EDRF release

- Basal state release of EDRF

- Acetylcholine release of EDRF

- Pressure-effects on the release of EDRF

- Effects of hypoxia and anoxia on EDRF release

Vasoactive substance

- Purinergic vasodilatation via endothelium

- Vascular response to histamine

- Vascular response to kallikrein

- Platelet aggregation and vasomotor tone

- Peptides and vascular response

Prostacyclin

Endothelium-derived hyperpolarizing factor (EDHF) and endothelium-derived contracting factors (EDCF)

Endothelium-derived relaxing factor and anaesthetic agents

Pathophysiology

- Subarachnoid haemorrhage

- Angioplasty

- Arterial and venous coronary artery bypass

- Hypercholesterolaemia and lipid disorders

- Coronary artery disease

- Hypertension

- Diabetes mellitus

- Septic shock

Conclusion 
The purpose of this review is to provide anaesthetists with a comprehensive update on the endothelial-cell control of local blood flow in health and disease. It has become apparent in the last decade that vascular endothelium plays a major role in the coordination and control of the tone of blood vessels throughout the arterial and venous systems. Not only is it relevant in vasomotor tone regulation but also in modulating the inflammatory response, haemostasis, vascular cell growth and transcellular metabolism. ${ }^{1-13}$ Certain pathophysiological conditions such as atheroma, diabetes, hypertension, immunological diseases, vasospasm following balloon catheter angioplasty, and accelerated arteriosclerosis in heart transplantation are associated with impaired endothelial function. $1,2,4,5,7-10,14$

The vascular endothelium constitutes a single layer of thin squamous cells lining the intimal surface of the circulatory system. In humans, the endothelium has a surface area similar to that of six tennis courts and weighs 1 to $1.5 \mathrm{~kg}$. This layer of cells, originally thought to represent only a passive diffusion barrier between the circulating blood and the interstitial tissue, constitutes a very active tissue with a broad variety of biological actions (Table I). It is implicated in the production of antithrombotic substances as well as in promoting thrombosis and in activating the coagulation system. Also, the vascular endothelium participates in the uptake and metabolism of circulating vasoactive compounds. Through this metabolic activity, the vascular endothelium has an important regulatory effect on the regional blood concen-

\section{GLOSSARY}

Acetylcholine (ACh)

Adenosine diphosphate (ADP)

Adenosine triphosphate (ATP)

Atrial natriuretic peptide (ANP)

Calcitonin gene-related peptides (CGRP)

Coronary artery disease (CAD)

Cyclic adenosine monophosphate (cAMP)

Cyclic guanosine monophosphate (cGMP)

Diethyldithiocarbamate (DETCA)

Endothelin (ET)

Endothelium-derived hyperpolarizing factor (EDHF)

Endothelium-derived relaxing factor (EDRF)

Endothelium-derived contracting factors (EDCF)

Hydroxy-L-arginine (L-HO Arg)

L-N-mono-methyl-arginine (L-NMMA)

Mean alveolar concentration (MAC)

Messenger ribonucleic acid (mRNA)

Nitric oxide (NO)

Prostacyclin (PGI 2)

Serotonin (5-HT)

Substance P (SP)

Vasoactive intestinal peptide (VIP)
TABLE I Biologically active substances produced or metabolized by the vascular endothelium

Antithrombotic substance

Alpha 2-macroglobulin

Antithrombin III

Heparin sulphate

Plasminogen activator

Prostacyclin

Protein C

Metabolized substances

Adenine nucleotides

Adenosine

Angiotensin I and II

Bradykinins

Leukotrienes

Norepinephrine

Prostaglandins

Serotonin

Substance $P$

Substances promoting thrombosis or activating the coagulation system Fibronectin

Platelet aggregating factor

Thromboplastin

Thromboxane $\mathrm{A}_{2}$

von Willebrand factor

Secreted substances

Endothelial-derived constricting factors

Endothelial-derived hyperpolarizing factor

Endothelial-derived relaxing factor

Prostacyclin

trations of these circulating vasoactive substances. This constitutes one mode of action for the regulation of the local blood flow by the vascular endothelium. The endothelium is able to modulate blood flow further by the secreting vasoactive substances such as: (1) prostacyclin, (2) a non-prostanoid endothelium-derived relaxing factor (EDRF), (3) an endothelium-derived hyperpolarizing factor (EDHF), and (4) at least two endothelium-derived contracting factors (EDCF).

\section{Historical perspective of endothelium-derived relaxing factor(s) (EDRF)}

The discovery of a relaxing substance came from the work of Furchgott and Zawadzki. ${ }^{15}$ They showed that acetylcholine ( $\mathrm{ACh}$ ) evoked relaxation of isolated preparations of arteries of rabbits which had been pre-contracted by the addition of an exogenous constricting agent (norepinephrine) was dependent on the presence of endothelial cells. In subsequent studies, they extended this finding to all mammals. ${ }^{9,10}$ The mechanism of release of this endothelium-derived factor(s) is associated with ACh stimulation of a muscarinic receptor on the endothelial cell (Figure 1).

The duration of action of this vasodilating factor has 


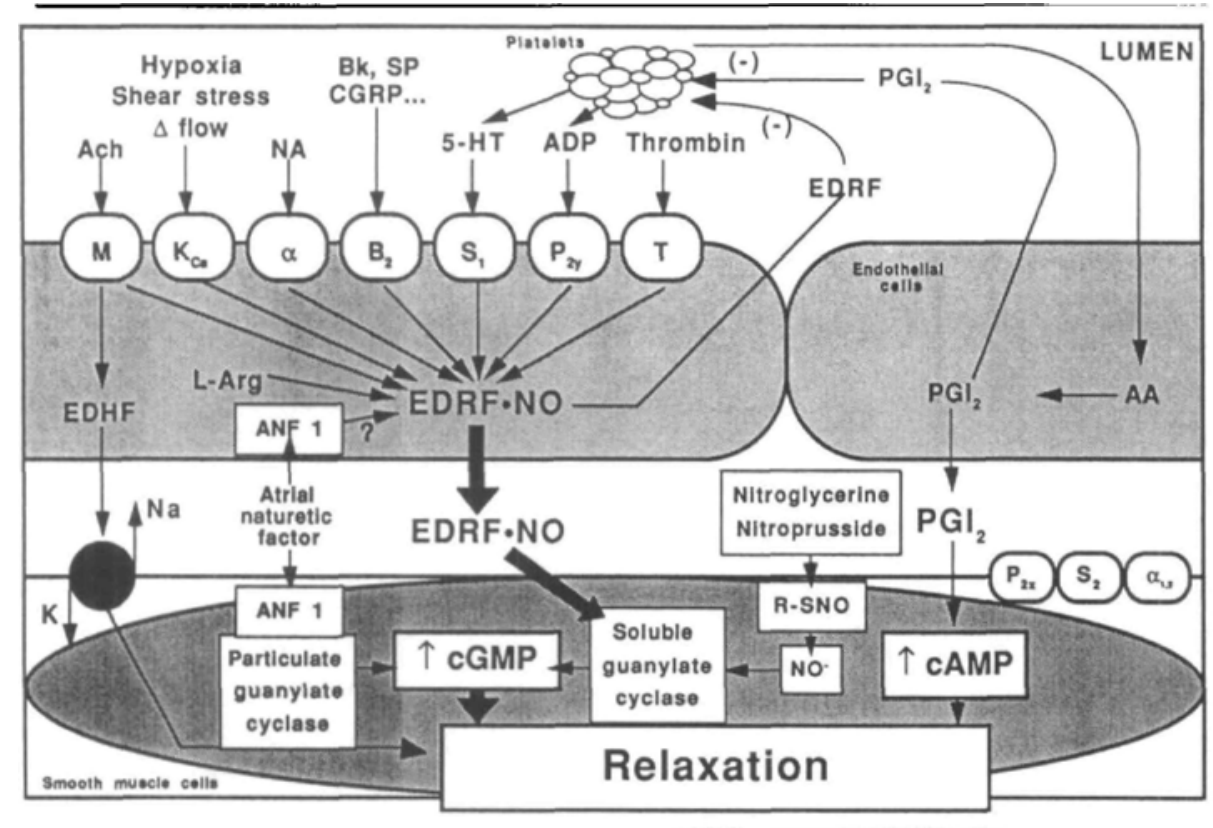

FIGURE 1 Mechanism of endothelium-dependent vasodilatation. Vasoactive substances and changes in flow stimulate endothelial cells to release EDRF (endothelium-derived relaxing factor), a powerful vasodilator substance. The EDRF induces relaxation of vascular smooth muscle cells through elevation of cyclic GMP (cGMP). Prostacyclin (PGI 2) is another endothelium-derived vasodilator acting through an increased formation of cyclic AMP (CAMP). The endothelial cell also produces a hyperpolarizing factor (EDHF) which causes relaxation of vascular smooth muscle cells through activation of sodium-potassium pumps. EDRF and PGI 2 are also released into the lumen, where they inhibit platelet aggregation synergistically. Acetylcholine (ACh); bradykinin (Bk); substance $\mathrm{P}$ (SP); calcitonin gene-related peptide (CGRP); noradrenaline (NA); serotonin (5HT); adenosine diphosphate (ADP); L-arginine (L-Arg); arachidonic acid (AA); atrial natriuretic factor (ANF); muscarinic receptor (M); serotonic receptor (S 1); purinergic receptor ( $P$ 2x and $P$ 2y); adrenergic receptor $(\alpha)$; and thrombin receptor $(T)$ (adapted from Vrints and Herman ${ }^{4}$ with permission).

been determined by bioassay. Griffith $e t$ al. ${ }^{16}$ determined that EDRF had a biological half-life of $6.3 \mathrm{sec}$. Subsequent bioassay studies, in which the release of EDRF from cultured endothelial cells was monitored, showed that EDRF is rapidly inactivated by oxygenated buffer solutions, methylene blue, haemoglobin, free iron, and superoxide radicals, while anoxia prevents the synthesis of EDRF. ${ }^{4,16,17}$ To deplete the cytosol of superoxide dismutase (SOD) of bovine coronary arteries by the use of diethyldithiocarbamate (DETCA) inhibited ACh stimulated EDRF-dependent relaxation as well as inhibiting the effect of the nitrovasodilators (nitroglycerine and nitroprusside). ${ }^{18-20}$ The lack of SOD activity increased the concentration level of superoxide anions thus inhibiting EDRF and nitrovasodilator action while the addition of SOD to the isolated arteries restored the effect of ACh and also that of nitrovasodilators. Therefore, the control of cellular superoxide anion levels by superoxide dismutase appears necessary for the action of EDRF and for the response of the nitrovasodilators on vascular smooth muscle. Indeed, although nitrovasodilators and organic nitrates differ in various aspects, their common principle is the capacity to release nitric oxide (NO) from their molecule.

The similarities in the mechanisms of smooth muscle relaxation caused by the endothelium-dependent vasodilators and nitrovasodilators (nitroglycerine and nitroprusside) which were known to release NO suggested that EDRF may be the same intermediary. Formal demonstration that EDRF is NO came from experiments done by Ignarro $e t a l^{8}$ who showed that EDRF and an aqueous solution of NO had striking pharmacological similarities and that, under spectrophotometric analysis, EDRF and NO produced an identical spectral shift in the absorbance of haemoglobin. Using chemiluminescence, Palmer et $a l^{21,22}$ demonstrated that the NO, liberated by bradykininstimulated endothelial cells, could be accounted for quantitatively and that the precursor substance for NO synthesis was L-arginine. Nitric oxide is synthesized by oxidation of the guanidino-nitrogen of arginine. The cytosolic enzyme which is necessary is activated by interaction of calcium and calmodulin and requires nicotinamide adenine dinucleotide phosphate as a cofactor 


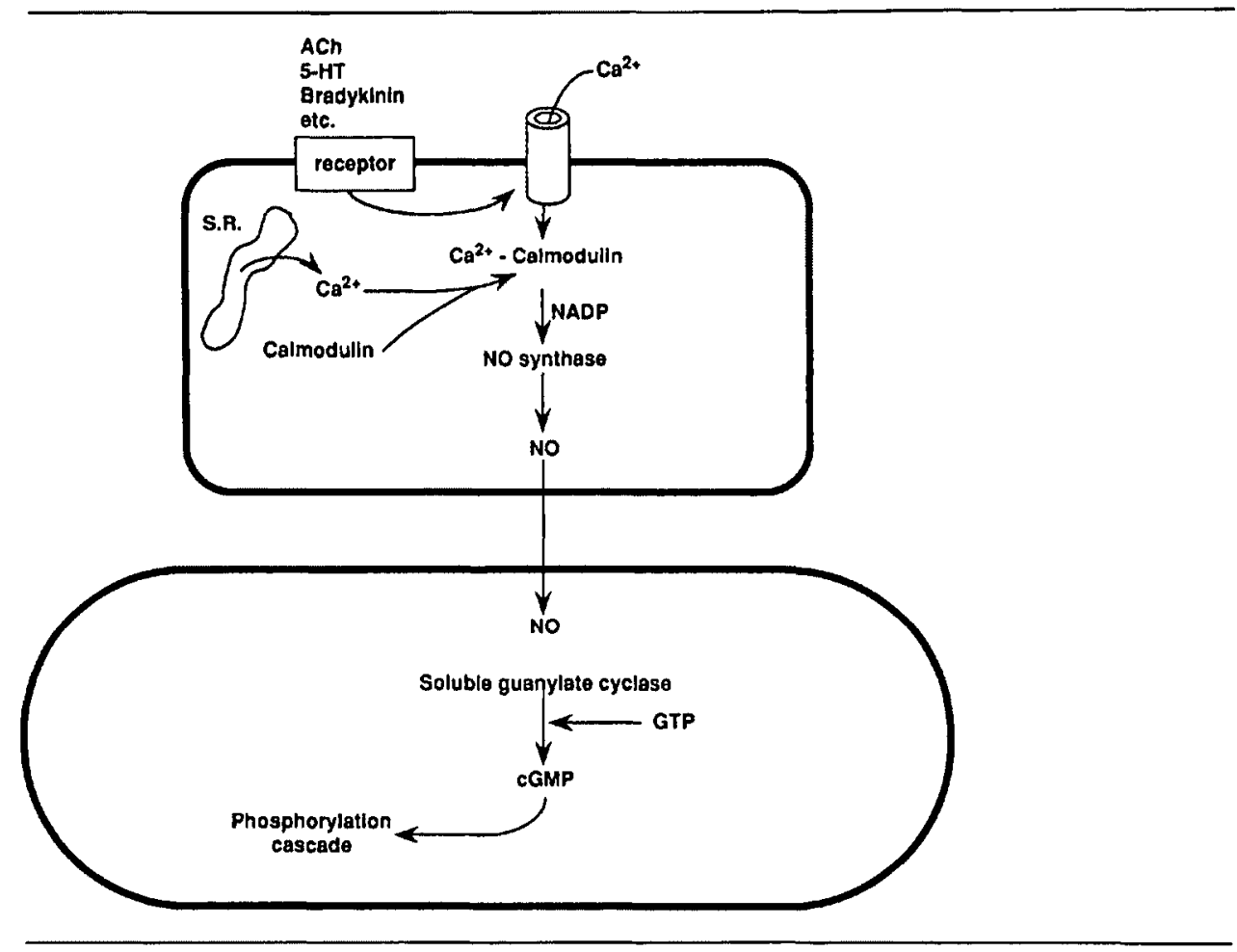

FIGURE 2 Substrate and cofactor requirements for nitric oxide (NO) synthase activation.

(Figure 2). ${ }^{23}$ The mechanism of release of free NO has been questioned. It may not be released directly but via a more stable compound such as S-nitrosocysteine which, subsequently, at the level of the cell membrane, dissociates with the formation of $\mathrm{NO}^{24}$ Zembowicz et al. ${ }^{25}$ have presented evidence that not only NO is released but also another more stable and more potent vasodilator is formed from hydroxy-L-arginine (L-HOArg) by cultured endothelial cells. This novel vasodilator appears to be derived from a chemical reaction between NO and L-HOArg which may indicate that a second endothelial-derived relaxing factor is produced by endothelial cells.

\section{Biochemical action of EDRF}

Nitric oxide is a simple gas which is highly reactive. Endothelial-derived relaxing factor, produced from the endothelial cell, will rapidly penetrate through the smooth muscle cell membrane and bind to the haeme portion of soluble guanylate cyclase. It will activate guanosine cyclase to increase the intracellular concentration of cyclic guanosine monophosphate (cGMP). ${ }^{26-29}$ The EDRFinduced increase of cGMP reduces the intracellular calcium level in vascular smooth muscle by several possible mechanisms. One of these is the inhibition of hydrolysis of phosphatidylinositol which, secondarily, mobilizes calcium from the sarcoplasmic reticulum. In addition, elevated concentration of cGMP can increase calcium uptake by the sarcoplasmic reticulum, decrease the sensitivity to myosin light chain for calcium, and interfere with receptor-operated calcium channels. Thus, the overall effect is decreased intracellular calcium. Aside from increasing intracellular cGMP, EDRF can induce transient hyperpolarization of vascular smooth muscle by activating the sodium-potassium pump. ${ }^{30}$ These effects on the smooth muscle cell membrane may only partially explain the endothelium-dependent relaxations evoked by locally released factors or physical stimuli.

\section{Physiological stimulants of EDRF release}

\section{Basal state release of EDRF}

In a basal, non-stimulated state, EDRF is produced and released continuously. Continuous release of EDRF may be due to viscous drag induced by shear stress and by the pulsatile nature of the arterial flow (Figure 3). The flowinduced shear stress, acting on the endothelial cell, is probably the most important stimulus for endothelialdependent control of vascular tone..$^{31-37}$ This endotheliumdependent reaction plays an important role in modulating systemic and pulmonary vascular resistance. Basal EDRF activity is present in all arterial preparations tested. Chu et $a l .{ }^{38}$ demonstrated that NO modulated epicardial coronary basal vasomotor tone in awake dogs. After infusing an 


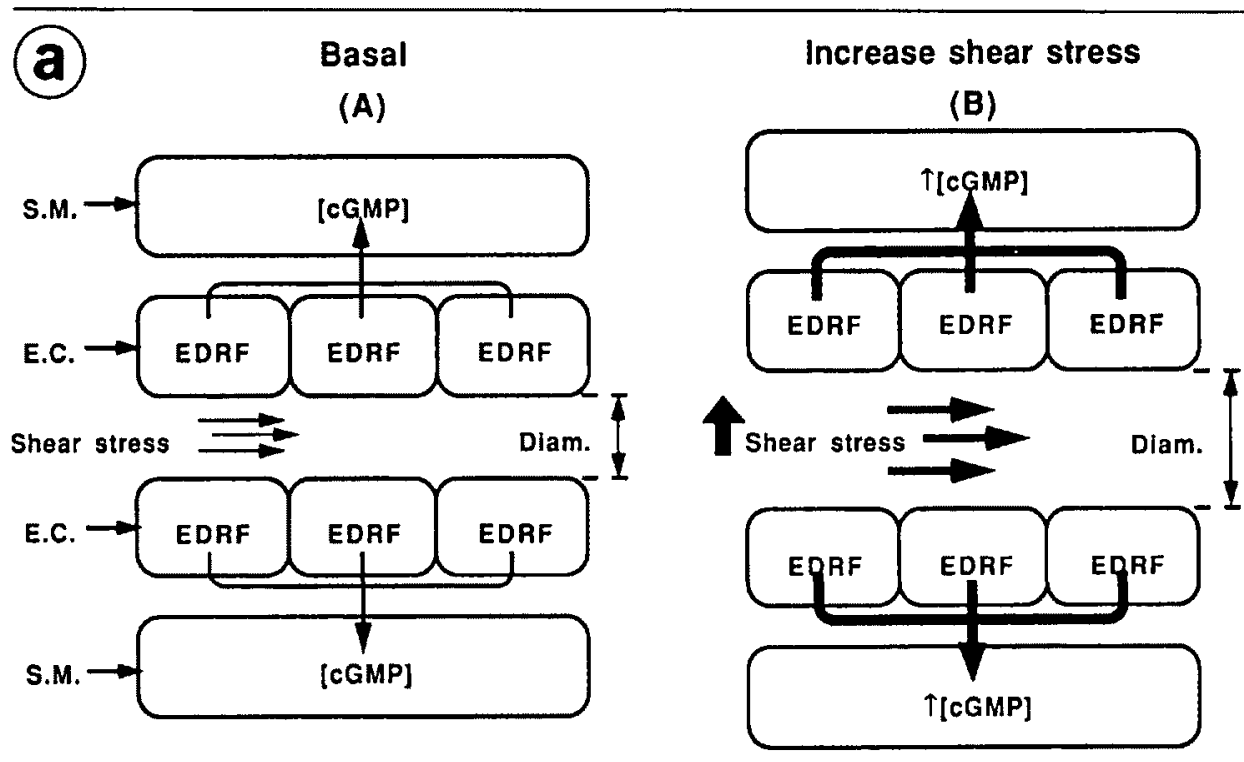

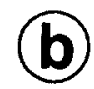

Basal state

(A)

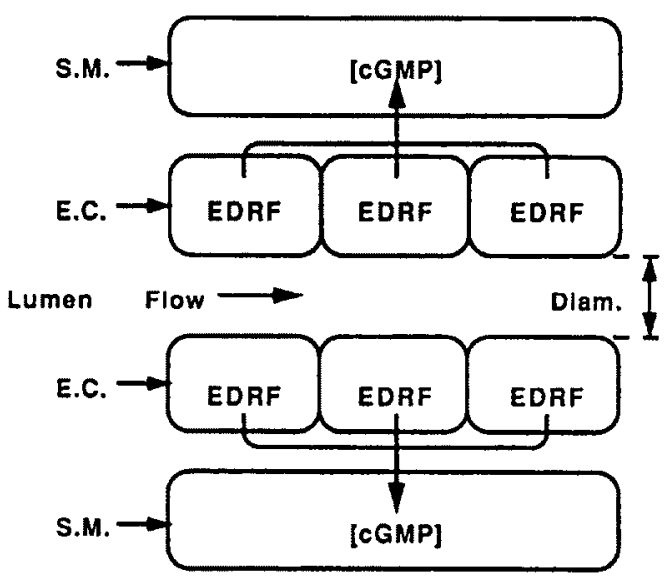

Increase flow

(B)

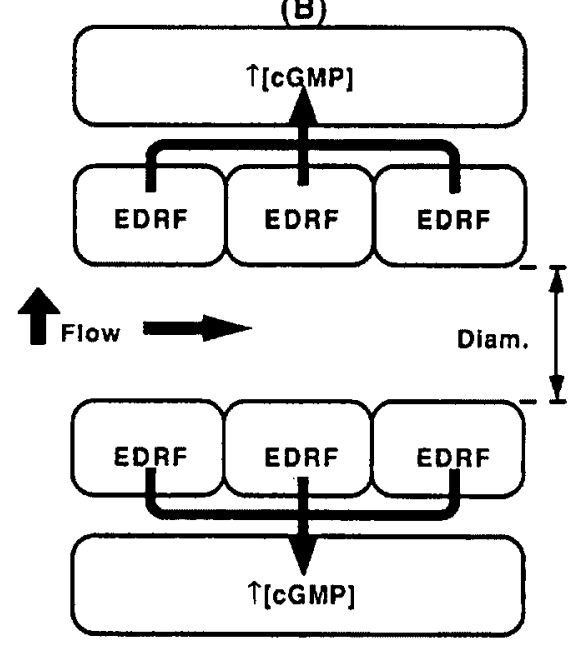

FIGURE 3 Schematic representation of EDRF-release under basal state (a) and with the increase in flow and/or shear stress (b). Increase flow leads to endothelial liberation of EDRF which diffuse through the smooth muscle membrane to increase cyclic guanosine monophosphate (cGMP). Smooth muscle (S. M.), endothelial cell (E. C.), diameter (Diam.).

inhibitor of NO synthesis, L-N-mono-methyl-arginine (LNMMA), they noticed a gradual decrease in the arterial diameter, increase in systemic blood pressure which was reversible only after reinfusion with L-arginine. Following prolonged administration of L-NMMA persistent hypertension with decreased vascular compliance was seen in all vascular beds. ${ }^{39}$ The inability of the vascular system to readjust to baseline values suggested that the basal release of EDRF was of major importance for local vascular control. Several studies have established that coronary arteries seem more reactive than peripheral arteries to endothelial-derived vasoactive substances. This may be related to a greater release of vasoactive substances or to a greater effector response. $4,5,16,38,40,41$ This flowdependent control seems to be of particular importance in the coronary circulation where moment to moment variability and an extremely pulsatile flow pattern is present. Aside from this basal release, a variety of physiological stimuli and vasoactive substances stimulate the endothelium to release EDRF (Table II). 
TABLE II Stimulants of EDRF release

Physiological

Change in flow or shear stress

Change in oxygen tension

Vasoactive substances

Acetylcholine

Adenosine diphosphate

Adenosine triphosphate

Bradykinin

Calcitonin gene-related peptide

Calcium ionophore (A23187)

Cholecystokinin

Histamine

Noradrenaline

Serotonin

Substance P

Thrombin

Vasoactive intestinal peptide

\section{Acetylcholine release of EDRF}

As mentioned previously, acetylcholine is the classic means to induce EDRF release in isolated arteries. Acetylcholine stimulates muscarinic receptors on the endothelial cell of the coronary and peripheral arteries. ${ }^{15.42-46}$ There is some inconsistency regarding the action of $\mathrm{ACh}$ on endothelial cell release of EDRF. Knight et al. ${ }^{47}$ in intact sedated baboons, demonstrated that intracoronary injection of $\mathrm{ACh}$ in high doses caused coronary constriction with decreased coronary blood flow and contractility without any systemic haemodynamic changes. In contrast, low doses of ACh caused only coronary vasodilatation. These $A C h$ responses were unaffected by $\alpha$ and $\beta$ adrenoceptor blockade but were abolished by atropine. Acetylcholine administered in the baboons' iliac artery, at any dose, caused vasodilatation. This variability of $\mathrm{ACh}$ effects on different arterial beds may be explained by differences in species, doses or possibly, at high doses, the liberation of endothelial constricting factor(s).

The physiological role of these endothelial cells muscarinic receptors is still unclear. The $\mathrm{ACh}$ molecules released at the nerve ending are rapidly destroyed and are unlikely to be present in any measurable concentration in the circulating blood. To advocate abluminal (directed away from the lumen) release of $\mathrm{ACh}$ from neural tissue implies that $\mathrm{ACh}$ diffuses some distance to stimulate the endothelial cell. Diffusion of $\mathrm{ACh}$ through the subendothelial space appears to be inefficient. Furthermore, the inability to identify muscarinic cholinoceptors on the surface of endothelial cells autoradiographically is puzzling. ${ }^{48}$ Recently, evidence has been accumulated indicating that some endothelial cells contain ATP, serotonin and substance $P(S P)$ and may possess enzymatic activity of choline acetyl transferase and, hence, are able to synthesize acetylcholine. ${ }^{49-52}$ The questions that may be asked are whether the endothelial cell can synthesize $\mathrm{ACh}$ and/or whether it can release vasoreactive substances? If certain endothelial cells are able to release vasoactive substances and can synthesize $\mathrm{ACh}$ then, under appropriate conditions, these "special" endothelial cells might liberate substances which can interact with neighbouring endothelial cells to release EDRF. ${ }^{4}$

\section{Pressure effects on the release of EDRF}

With the augmentation of flow through large arteries, the increase in transmural pressure leads to a proportionate increase in EDRF (Figure 3). This response improves organ perfusion. Holtz et al..$^{37,53}$ demonstrated in conscious dogs that an increase in coronary blood flow was matched by an increase in coronary artery diameter but this vasodilatation was not seen in endothelium-denuded coronary arteries. ${ }^{1,2,4}$ Endothelial-derived relaxing factor is not only a vasodilator but may also act as a second messenger to modify the production of vasoactive substances in other cells. Exposing slices of canine kidney to EDRF released from isolated blood vessels reduced renin production. ${ }^{54}$ The anatomical proximity of the juxtaglomerular cells and the endothelial cells of the preglomerular arterioles may modulate renin release to EDRF in response to changes in perfusion pressure. It appears therefore that arterial flow variation is continuously monitored by the endothelium. Hence endothelial cells may act as local baroreceptors and modulate organ perfusion. The exact flow-sensing mechanism is not presently known, but Olesen et al. ${ }^{55}$ demonstrated a flow-dependent vasodilatation linked to activation of potassium channels leading to hyperpolarization of smooth muscle cells. Recently Cooke et al ${ }^{56}$ reported that increased flow activated an endothelial potassium channel which was able to release an endogenous nitrovasodilator (NO). The mechanical deformation of the endothelial membrane may represent an important flow-sensing mechanism for endothelial cell control of arterial diameter.

\section{Effects of hypoxia and anoxia on EDRF release}

A continuous supply of oxygen is of vital importance for all living cells. This goal is achieved by several independent mechanisms to maintain an adequate supply of oxygenated blood for a broad range of metabolic demands. One of these mechanisms might be the direct effect of oxygen on endothelial cells. Release of EDRF is observed in rabbit aorta and femoral arteries subjected to hypoxia. ${ }^{57}$ Interestingly the presence of calcium in the incubating medium is essential for EDRF synthesis and/or release under hypoxic conditions. ${ }^{57}$ As mentioned before, the presence of haemoglobin or higher concentrations of superoxide-free radicals was able to attenuate substantially the hypoxic release of EDRF. ${ }^{58,59}$ 
Endothelial cells seem to behave as functional oxygen sensors in the vascular wall. Vasomotion in response to local changes in $\mathrm{PO}_{2}$ may be, at least in part, secondary to oxygen-induced changes in the release of EDRF. But EDRF is not the only factor that may be released. When the $\mathrm{PO}_{2}$ falls to a critical level, endothelial cells cease to release EDRF and synthesis of some endothelium-dependent vasoconstricting factors (EDCF) may be activated. Recently, Kourembanas et al. ${ }^{60}$ showed that hypoxia $\left(\mathrm{PO}_{2}\right.$ $30 \mathrm{mmHg}$ ), in cultured human endothelium, was able to induce the endothelin gene and secretion of endothelin, while the reinstitution of a normal $\mathrm{PO}_{2}$ was able to reverse this reaction. Thus, the low oxygen tension which may occur in the microcirculation might act as a continuous physiological stimulus for the release of EDRF and/or endothelin, thus contributing to the local regulation of vasoconstriction and vasodilatation. ${ }^{4}$

Anoxia, in canine femoral arteries, abolished AChinduced relaxation and, at the same time, enhanced constrictor response to norepinephrine. ${ }^{10}$ Other stimulants of EDRF release, for instance, calcium ionophore A23187 (non-receptor dependent generator of EDRF) and bradykinin (receptor-dependent generator of EDRF), were also inhibited during anoxia. This suggests that EDRF production may be interrupted during anaerobic conditions. Similar results have been obtained with inhibitors of the mitochondrial electron transfer chain. ${ }^{57}$

\section{Vasoactive substances}

\section{Purinergic vasodilatation via endothelium}

While the potent actions of purines on blood vessels have been known for many years, it is only recently that the various mechanisms involved have been understood. Adenosine triphosphate and ADP receptors (purinoceptors) are present on the vascular endothelial and smooth muscle cells. The endothelial cell purinoceptor $\left(P_{2 y}\right.$ subclass) produces vasodilatation via EDRF release similar to ACh stimulation ${ }^{50,52}$ Contrary to endothelial cells, smooth muscle cells have two subclasses of purinoceptor population $\left(\mathrm{P}_{2 \mathrm{x}}\right.$ and $\left.\mathrm{P}_{2 \mathrm{y}}\right)$. Stimulation of $\mathrm{P}_{2 \mathrm{x}}$ leads to vasoconstriction while $P_{2 y}$ leads to vasodilatation. The overall smooth muscle cell response depends on the predominance of one subclass of receptor and the local production of EDRF.

Release of purine transmitter substance is not only derived from aggregating platelets but also from specialized non-sympathetic purinergic neurons and from endothelial cells. Several studies have demonstrated the existence of non-sympathetic purinergic innervation causing vasodilatation of the rabbit portal vein ${ }^{61}$ and of vessels of skeletal muscle, ${ }^{62,63}$ and vasoconstriction of intrapulmonary arteries. ${ }^{64}$ The possibility that there are some intrinsic purinergic cardiac neurones for vasodilatation of the coronary vessels has been raised..$^{65}$

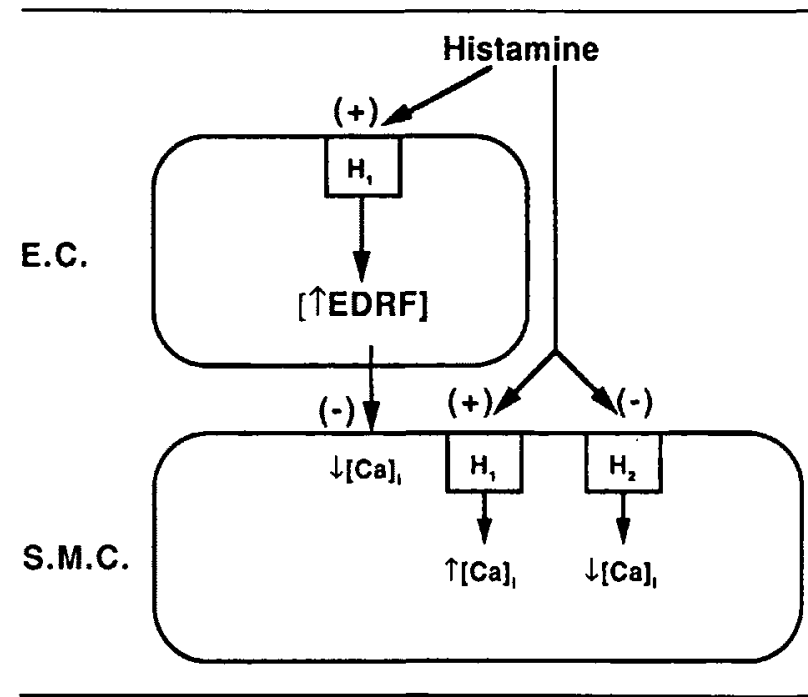

FIGURE 4 Effect of histamine on endothelial and a smooth muscle cell response to stimulation. Histaminergic receptors (H-l and H-2), calcium (Ca), endothelial cell (E.C.) and smooth muscle cell (S.M.C.).

\section{Vascular response to histamine}

Anaesthetists are wary of drugs which have the propensity for histamine release because of the severe haemodynamic effects. The profound depression of blood pressure produced by intravenous histamine administration is due to a decrease in vascular tone, a direct action on cardiac muscle and an increase in capillary permeability. These effects are the results of a complex interaction with both types of histaminic receptors (H-1 and $\mathrm{H}-2)$ located on the endothelial (H-1) and smooth muscles ( $\mathrm{H}-1$ and $\mathrm{H}-2)$ cells leading to heterogenous responses from different vascular beds and in different species (Figure 4). ${ }^{43,66,67}$

The vasoconstricting effect of stimulation of the $\mathrm{H}-1$ histaminergic receptors located on vascular smooth muscle is tempered by the effect of stimulation of endothelial histaminergic receptors releasing EDRF. Again the overall vascular response of histamine probably depends on the sensitivity and reactivity of both histaminergic receptor populations. Under pathological states (coronary atherosclerosis) uncoupling of these opposing forces will lead to a predominant vasoconstriction or vasospasm. Administration of histamine in atherosclerotic rabbit coronary arteries leads to vasoconstriction and myocardial ischaemia ${ }^{68}$ while a similar administration of histamine in patients with coronary disease (CAD) resulted in vasospasm. ${ }^{69}$

\section{Vascular response to kallikrein}

The intravenous administration of bradykinin produces hypotension by decreasing the peripheral resistance and increasing the vascular permeability at the level of the microcirculation. Because of its low plasma concentration, under physiological conditions, bradykinin contributes little to the maintenance of vascular tone. 


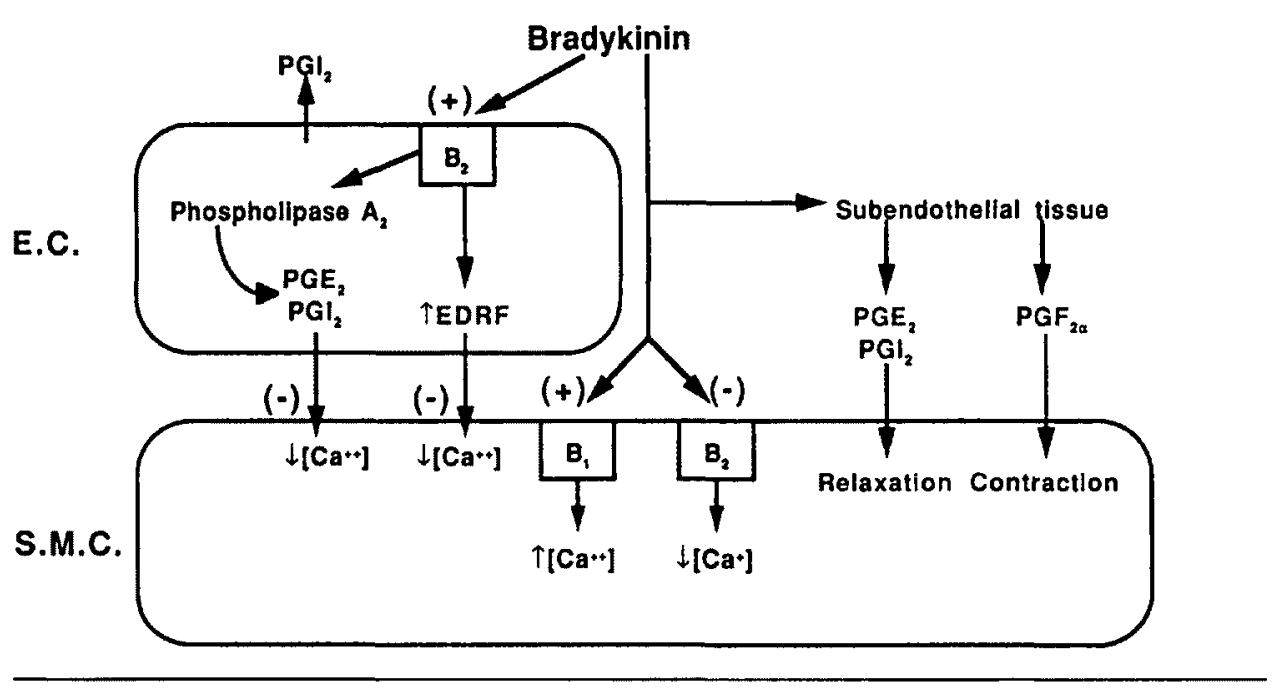

FIGURE 5 Effect of bradykinin on endothelial, subendothelial tissues and smooth muscle cell. Endothelial cell (E.C.), smooth muscle cell (S.M.C.), prostaglandins (PGI 2, PGE 2 and PGF $2 \alpha$ ).

The cardiovascular actions of bradykinin are related to the following properties: (1) stimulation of a bradykinin receptor (B-2) on the endothelial cell, (2) stimulation of production of different prostaglandins from endothelial cells and from subendothelial structures, and (3) stimulation of a different subclass of bradykinin receptor located on the smooth muscle cells. The arterial vasodilatation produced via B-2 endothelial receptor stimulation is mediated by EDRF, PGI 2 and PGE 2 secretion, whereas, in veins, bradykinin preferentially liberates PGF $2 \alpha$ (vasoconstrictor) instead of PGE $2 .^{70}$ This may explain the venous contraction observed following bradykinin exposure. With regard to smooth muscle cells, activation of the bradykinin receptors causes contraction. Using denuded arterial rings, Cheng et al..$^{71}$ and Förstermann et al. ${ }^{72}$ demonstrated a predominant vasodilatation response to bradykinin even in the absence of endothelial cells. Pretreating intact porcine coronary arteries with the following agents: NO inhibitor (L-NMMA), soluble guanylate cyclase inhibitor (Methylene blue) and $\mathrm{G}_{\mathrm{i}}$ protein inhibitor (Pertussis toxin) still induced vasodilatation to bradykinin stimulation. ${ }^{73}$ These findings lend support to the hypothesis that the vasodilating prostaglandins and/or other endothelial-derived vasodilator(s) may play a determinant role in arterial vascular tone (Figure 5).

\section{Platelet aggregation and vasomotor tone}

Endothelial cells are involved in the balance between coagulation, thrombus formation, and fibrinolysis. Plasminogen activator and anti-thrombin III released from the endothelium promote fibrinolysis and the presence of heparin sulphate at the cell membrane suppresses thrombosis. The inhibitory effect on platelet aggregation and thrombus formation of $P G I 2$ and $E D R F$ is directly related to endothelial-released factors. ${ }^{74}$ Prostacyclin and EDRF can potentiate each other at subthreshold concentrations and prevent platelets from aggregating. It is important to mention that aggregating platelets release sufficient mediators to cause endothelial-dependent relaxation in normal human arteries. ${ }^{75}$ Thus the released EDRF and PGI 2 provide a negative feedback to aggregating platelets, increasing blood flow (by vasodilatation) and thus diluting platelet mediators. Also, activated platelets participate in endothelial cell synthesis of PGI 2 via the release of endoperoxides and arachidonate precursors for production of PGI $2{ }^{76}$ This phenomenon is known as transcellular metabolism. In these reactions one cell uses precursors and intermediates from another for the production of a new metabolite(s) with entirely different functions. Furthermore, biochemical and functional data indicate that in aspirin-treated endothelial cells where no $P G I 2$ production is inhibited and where no measurable EDRF, there is an alternative mechanism for platelet inactivation. This new mechanism involves the degradation of ADP by an endothelial membrane-bound enzyme (endothelial membrane ecto-adenosine diphosphatases) which consequently inhibits platelet proaggregatory activity. ${ }^{76}$ The summation of these endothelial-cell mechanisms is responsible for maintaining the haemostatic system under control.

Serotonin released from aggregating platelets exhibits a complicated pattern of actions in the coronary arterial bed. It causes both dilatation and constriction of large and small coronary arteries. ${ }^{40,77-80}$ The vasodilatation is endothelium-dependent and originates from stimulation of serotonergic (S-1) receptors on the luminal side of endothelial cell membrane with liberation of EDRF. If these vessels are denuded of their endothelium then constriction is observed which is mediated by direct activation of 


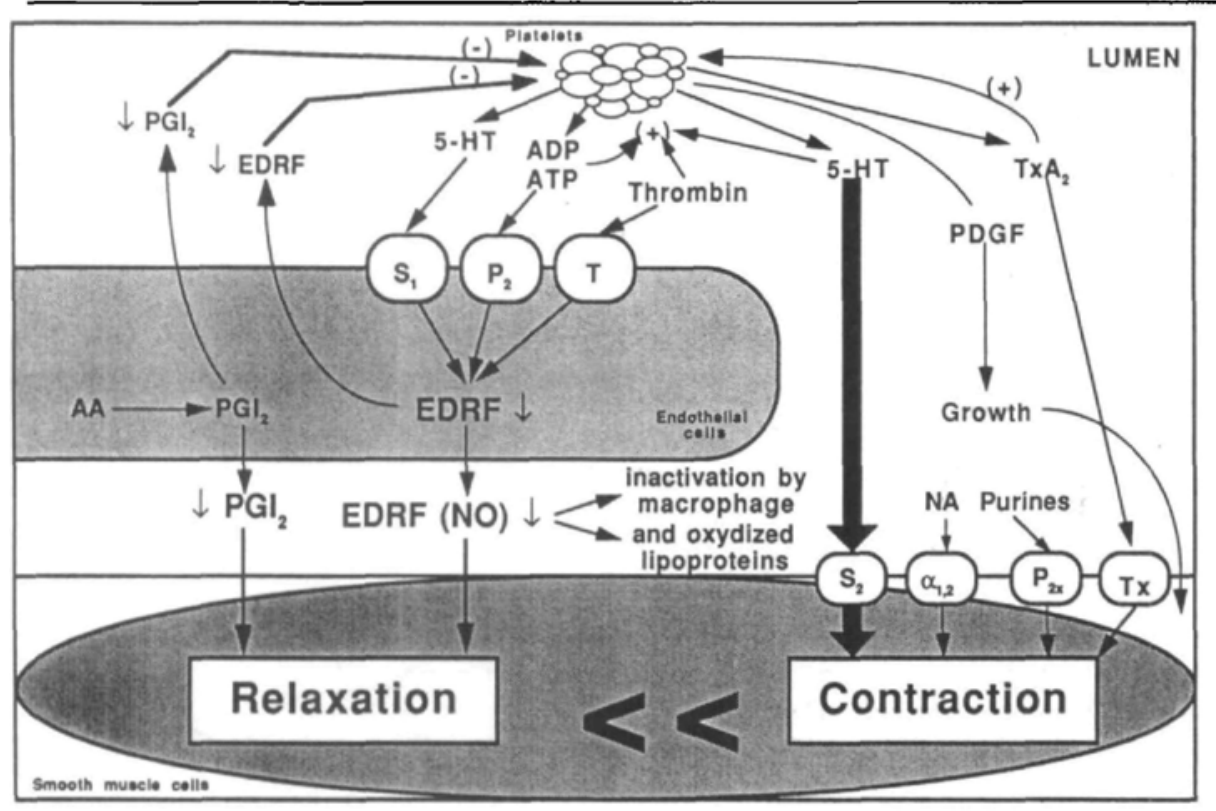

FIGURE 6 Illustration of platelet-vessel wall interaction and the effects of atherosclerotic coronary arteries causing impaired endothelium-dependent dilatation. A decrease in PGI 2 and EDRF production and/or inactivation is unable to inhibit platelet aggregation while platelet-derived products are still able to have full effect on smooth muscle cell. As a result, vasoconstrictor response to serotonin (5-HT) and thromboxane $A_{2}$ (TxA $A_{2}$ will predominate. Arachidonic acid (AA), serotonin receptor (S), purine receptor (P), thrombin receptor (T), alpha-adrenergic receptor $(\alpha 1,2)$, platelet-derived growth factor (PDGF), prostacyclin (PGI 2), adapted from Vrints and Herman ${ }^{4}$ with permission.

serotonergic (S-2) receptors on smooth muscle cell. Under normal physiological conditions, the $S-1$ receptor mediates a dominant endothelium-dependent dilatation. Under pathophysiological conditions (atheroma, atherosclerosis, thrombosis, etc.) there may be a shift in the vasomotor balance towards constriction when the intima is damaged and platelets come in contact with the subendothelial structures and release their content. Aggregating platelets are capable of releasing enough serotonin locally to evoke either constrictor or dilator responses. ${ }^{80,81}$ In addition, the responsiveness of the blood vessel wall to serotonin can be amplified in the presence of hypoxia, ${ }^{51}$ while an exaggerated response to serotonin is seen in hypertensive or atherosclerotic vessels (Figure 6). ${ }^{80,82,83}$

Another vasoactive compound released from aggregating platelets is thromboxane $A_{2}$. Thromboxane causes direct vasoconstriotion but has no endothelial-mediated effects.

The release of platelet activating factor (PAF) derived from platelets, neutrophils, mast cells and endothelial cells shows an endothelium-dependent vasodilatation only at higher concentrations. Platelet activating factor has a complex vasomotor effect because it is able to stimulate not only EDRF but also effect thromboxane and leukotriene release. For instance, intracoronary administration. of PAF initially causes vasodilatation that is not inhibited by indomethacin while the secondary vasoconstricting response which is dependent on thromboxane and leukotrienes release is indomethacin-sensitive. Thrombin, which is formed during the coagulation cascade, also evokes an endothelium-dependent relaxation (EDRF release) in various vessels including the coronary arteries and is capable of stimulating endothelin production. ${ }^{84,85}$

The ADP and ATP release from platelets has been discussed previously. In summary, platelet-derived vasoactive substances have opposing effects depending on the integrity of the endothelium. Under normal conditions, relaxation predominates over constriction but in denuded vessels an exaggerated vasoconstricting response (vasospasm) may be provoked when platelet-derived factors are released locally. Two other mechanisms were described by which the endothelial cells are able to maintain platelets from further aggregation: (1) secreted products of platelets (endoperoxides and arachidonate products) are used by the transcellular metabolism of endothelial cells to produce PGI 2 and (2) ADP derived from platelets are metabolized by an endothelial ADP-ase.

\section{Peptides and vascular response}

Mammalian atrial myocytes contain a group of peptides 
that possess natriuretic, aldosterone-inhibiting and vasorelaxant properties. ${ }^{86,87}$ These, the atrial natriuretic peptides (ANP), are important for central blood volume control in humans. The ANPs are rapidly released in response to changes in atrial pressure. In the human brachial artery, infusion of synthetic ANP causes a dosedependent vasodilatation that is rapid in onset $(30 \mathrm{sec})$ and maximal in two to three minutes. After cessation of the infusion, arterial dilatation persists for another 30 to 60 min. ${ }^{88}$ The rapid onset of vasodilatation suggests that the decrease in blood pressure during the systemic infusion of ANP is primarily due to vasodilatation rather than to volume loss through natriuresis. The plasma concentration of ANP capable of producing $50 \%$ vasodilatation in the previous study is well within the normal range measured in normal individuals.

The vasodilatation of ANP is heterogeneous being present in aortic, pulmonary, carotid and renal arteries but absent in coronary, mesenteric and femoral arteries. ${ }^{88}$ The mechanism is an increased level of cGMP in both the endothelial and the smooth muscle cells. The production of cGMP by ANP proceeds via particulate guanosine cyclase as opposed to soluble guanosine cyclase ${ }^{87}$ (Figure 1). While ANP secretion increases in response to atrial stretching, EDRF is able to modulate in a negative fashion the release of ANP. Removal of the atrial endocardium is responsible for increased release of ANP. This is directly related to a decrease in basal EDRF production either from the endocardium or from endothelial cells of coronary arteries since inhibitors of EDRF synthesis (haemoglobin, methylene blue and superoxide radicals) yield similar results. ${ }^{85}$ This indicates that released EDRF (second messenger) is able to influence atrial myocytes in the production and release of ANP.

The vasodilating effect of ANP is endothelium independent which is in contrast to other peptides, such as SP, calcitonin gene-related peptides (CGRP) and vasoactive intestinal peptide (VIP) all of which induce endotheliummediated dilatation (Figure 1). High vasodilator potency has been demonstrated for each of these peptides, $4,89-93$ and intracoronary application increases coronary flow. For $\mathrm{SP}$, intracoronary administration yielded different results in systemic and coronary beds. Initially, coronary vasodilatation prevailed with a gradual vasoconstriction that predominated during steady state conditions. ${ }^{93}$ The cause of the secondary vasoconstriction is not known. It may be related to liberation of a vasoconstricting substance from the endothelial cell. Although these vasoactive peptides circulate in measurable concentrations and affect vasomotor activity, they might also be secreted from the recently identified pericoronary nerves. ${ }^{92}$ Their overall contribution to the control of vascular tone in health and disease remains to be evaluated.

\section{Prostacyclin}

Prostacyclin (PGI 2) is a major prostaglandin produced by the endothelial cell. It has two major actions, firstly as a vasodilator and secondly by activating platelet adenylate cyclase and increasing platelet cAMP level, it inhibits platelet aggregation. Prostacyclin has a very short half-life of only one circulation time. Like EDRF, PGI 2 synthesis from endothelial cells is dependent on physical factors (pulsatile flow and shear stress) as well as endogenous mediators (bradykinin, thrombin, serotonin, plateletderived growth factor, interleukin- 1 and adenine nucleotides) and some drugs (calcium antagonist, captopril, dipyridamole, nitrates, diuretics and streptokinase) can stimulate its production. ${ }^{94}$ It has mainly a local effect. The endothelial production of PGI 2 decreases with age and in association with certain disease states, for instance, diabetes mellitus and atherosclerosis. ${ }^{94}$

Endothelium-derived hyperpolarizing factor (EDHF) and endothelium-derived contracting factors (EDCF) Endothelial cells secrete two other factors that influence vascular smooth muscle tone. Several workers have identified an endothelium-derived hyperpolarizing factor (EDHF) following ACh stimulation. Endothelial-derived hyperpolarizing factor is able to cause transient changes in the membrane potential of smooth muscle cells. The contribution of membrane hyperpolarization to endotheliumdependent relaxations induced by $\mathrm{ACh}$ was investigated in the femoral vein of the rat using a microelectrode technique. ${ }^{95}$ Acetylcholine caused endothelium-dependent relaxations and hyperpolarization in tissue contracted by norepinephrine. The relaxation to prolonged administration of ACh was sustained mainly by the release of endogenous nitrovasodilator while the hyperpolarization slowly declined with time. It appears that $\mathrm{ACh}$ proceeds via activation of M-1 muscarinic receptors to effect EDRF release while $\mathrm{M}-2$ muscarinic receptors leads to EDHF release. ${ }^{46,96,97}$ The chemical nature of EDHF is presently unknown.

Several experimental studies ${ }^{41}$ have now demonstrated the existence of an endothelial-derived constricting factor (EDCF). Endothelial-derived constricting factor can be released from endothelium in response to changes of pressure, rapid stretching, anoxia, electrical stimulation, large doses or repeated smaller doses of $\mathrm{ACh}$ and finally to arachidonic acid. In normal endothelium and in cultured endothelial cells, basal release of EDCF has been reported. ${ }^{98-100}$ One of the EDCF substances has been identified as a 21 -amino-acid peptide that has been named endothelin. ${ }^{101-103}$ Endothelin exists as a family of isoforms, ET1 to ET-3. ${ }^{104}$ Endothelin-1 is the only endothelin to be synthesized by the endothelial cells. Unlike EDRF and EDHF, endothelin has a longer-lasting vasoconstrictor 
effect in most but not all vascular beds. It is tempting to associate a physiological role for endothelin in the control of basal vascular tone and in pathophysiological states but this must await further investigations. Certain pathophysiological states such as cardiogenic shock ${ }^{105}$ and uraemia ${ }^{106}$ show elevated plasma endothelin levels while cyclosporin, ${ }^{107}$ transforming growth factor $\mathrm{B},{ }^{106}$ thrombin $^{101}$ and platelets ${ }^{108}$ stimulate pre-proendothelin mRNA synthesis and actual release of endothelin from cultured cells. Endothelium-derived NO can interfere with endothelin production. Endothelin production is increased in pre-treated porcine aorta by an inhibitor of EDRF synthesis when stimulated by thrombin. The opposite response was seen when superoxide dismutase was added to the system. Indeed any agent causing an increased level of cGMP will inhibit endothelin synthesis. ${ }^{100}$ Physical stimuli, such as increased shear-stress, caused suppression of endothelin gene expression and production. ${ }^{110}$ The potent endothelin-derived vasoconstriction may be antagonized by calcium channel blockers and/or by the lack of calcium in the extracellular medium. ${ }^{10}$

Presently, most authors are in agreement that circulating levels of endothelin are unlikely to affect systemic vasoconstriction but they do not rule out local vascular effects of endothelin. The endothelial cell has endothelin receptor located on the luminal side. Activation of these endothelial receptors brings about increase production of EDRF and/or PGI 2. Indeed, endothelin-1 can stimulate endothelial cells to secrete different vasodilating substances depending on the origin of the vascular endothelial cells. ${ }^{109}$ For instance, endothelial cel:s derived from porcine coronary artery vasodilate in response to ET-1 challenge by releasing PGI 2 while endothelial cells from rabbit abdominal aorta exposed to ET-1 responded by secreting NO. Compared to EDRF, endothelin has no platelet inhibitory activity at physiological concentrations but at high pharmacological doses, endothelin can stimulate prostaglandin synthesis that can indirectly affect platelet activity. ${ }^{110}$

The endothelium has been implicated in the production of two other vasoconstricting substances: (1) a cyclooxygenase product (i.e., a prostanoid or a superoxide anion) ${ }^{111}$ and (2) a non-prostanoid substance released during hypoxia. $^{4}$

\section{EDRF and anaesthetic agents}

Anaesthetic inhalational agents may cause some degree of arterial and venous vasodilatation whose cause is multifactorial. Investigating the interaction of inhalational agents on endothelial function especially in the coronary circulation is pertinent. Blaise et al. ${ }^{112}$ demonstrated that isoflurane $(2.3 \%, 1.5 \mathrm{MAC})$ attenuated the induced contraction of canine coronary preparation. This attenu- ation was endothelium-dependent. In the absence of endothelial cells, isoflurane had no effect on the serotonin and PGF $2 \alpha$-contracted coronary preparation but had a modest $\alpha$-adrenergic inhibitory effect. Bollen et al. ${ }^{113}$ found that halothane produced more relaxation than isoflurane in constricted segments of porcine coronary artery. Muldoon et al. ${ }^{114}$ questioned whether halothane altered endothelium-mediated vasodilatation of vascular smooth muscle in different preparations. Their results indicated that halothane (2\%) attenuated the $\mathrm{ACh}$ and bradykinin endothelium-mediated vasodilatation in carotid and aortic preparations, while the femoral artery preparation demonstrated intensification of the vasoconstriction. They postulated that halothane interfered with either the production, release or peripheral action of EDRF. Stone and Johns ${ }^{115}$ studied the effects of incremental doses $(0.5-5 \%)$ of halothane, enflurane and isoflurane on isolated aortic vascular rat preparations. They examined intact and denuded vessels which were pre-contracted by phenylephrine with and without the addition of indomethacin. Isoflurane and enflurane at low concentrations caused vasoconstriction while at higher concentrations vasodilatation was evident in vessels with intact endothelium. Overall, halothane was not different from controls in intact vessels. After discontinuation of all three agents there was a rebound vasoconstriction above the baseline value which was worse if the vessels had been pre-treated with indomethacin suggesting that cyclooxygenase inhibition by indomethacin prevented the synthesis of prostanoid relaxing factor(s). In denuded rings, a dose-dependent relaxation with all three inhalational agents was seen, i.e., direct $\alpha$-adrenergic inhibition, and incubation with indomethacin and/or removing the inhalational agent produced no change from the preconstricted value. The authors concluded that: (1) at low concentrations, enflurane and isoflurane inhibited EDRF production and/or promoted the release of an endothelial constricting factor, and (2) at higher concentrations, direct action on smooth muscle relaxation predominated $(\alpha-$ adrenergic antagonist), and (3) that indomethacin inhibited the production of a prostanoid vasodilating agent from the endothelium.

The in vivo and in vitro evaluation of isoflurane and halothane on the effects of serotonin (vasoconstriction) on porcine coronary arteries was assessed by Witzeling $e t$ al. ${ }^{116}$ They concluded that: (1) for all concentrations of either volatile agent, a reduction in the induced vasoconstriction was seen; (2) the vasodilatation in intact vessels was greater; (3) serotonin stimulated serotonergic receptors on both endothelial and smooth muscle cells with an overall effect of vasoconstriction and (4) in vivo, both isoflurane and halothane, $1.5 \%$, dilated constricted epicardial vessels. Greenblatt et al. ${ }^{117}$ in a complex experimental design examined the effect of isoflurane (1 MAC) and 
halothane (1 MAC) in indomethacin-treated animals that also received an inhibitor of EDRF synthesis (L-NMMA). Thus, they were able to separate the contribution from EDRF-dependent vasodilatation from the vasodilatation caused by inhalational agents and from that due to endothelial prostanoid synthesis. They extended their study to include vascular rings from major vascular beds (coronary, renal, carotid, etc.). They found that isoflurane, compared with halothane, demonstrated a greater dependency on released endothelial relaxing factors for its haemodynamic action. Furthermore, they showed that EDRF-mediated tone is more prominent in coronary, renal, hepatic, splanchnic and cutaneous circulation during isoflurane anaesthesia. Their data may help to explain the different peripheral vascular responses of isoflurane compared with halothane.

Pettis et al. ${ }^{118}$ evaluated the effect of nitrous oxide on pigs' coronary arteries. Nitrous oxide (70\%) decreased coronary artery diameter from control (70\% nitrogen). They could not attribute the vasoconstricting effect of nitrous oxide to increased norepinephrine level, or endothelial-derived endothelin secretion. Nitrous oxide vasoconstriction was antagonized by calcium channel blockers, nitroprusside and partly by phentolamine. Inhalation of nitric oxide in awake lambs resulted in reduction of the pulmonary artery pressures and resistances during infusion of a thromboxane analogue U46619 (pulmonary vasoconstrictor) and during neutralization of heparin anticoagulation by protamine sulphate (release of thromboxane during neutralization). ${ }^{119}$ Inhalation of NO did not have any systemic effects. This finding may have therapeutic importance in treating the catastrophic pulmonary hypertension secondary to neutralization of heparin by protamine following extracorporal circulation.

Recently, the role of some anaesthetic induction agents on the endothelial function has been evaluated. Propofol produced an endothelium-independent vasodilatation and may have a calcium channel blocking action. ${ }^{120}$ Ozhan et al. ${ }^{121}$ compared propofol with thiopentone contractile responses in isolated coronary arteries of pigs. Propofol had an intrinsic non-endothelium-dependent vasodilatation while thiopentone caused slight vasoconstriction. Neither induction agent altered endothelium-dependent relaxation. Etomidate produced a mixed endothelium-dependent and independent vasodilatation. ${ }^{122}$ In several species, high doses of fentanyl were devoid of major effects on the coronary vasculature. ${ }^{123}$ Local anaesthetics inhibited endothelium-dependent vasodilatation of isolated rat thoracic aorta. ${ }^{124}$ The local anaesthetics appeared to exert their inhibitory effects distal to receptor activation since the non-receptor activation by calcium ionophore A23187 was also inhibited. The endothelium-independent vasodilator sodium nitroprusside dilated the aortic rings pre-treated
TABLE III Pathophysiological state with impaired endothelial function

Subarachnoid haemorrhage

Following angioplasty

Arterial and venous coronary artery bypass

Hypercholesterolaemia and lipid disorders

Coronary artery disease

Hypertension

Diabetes mellitus

Septic shock

with local anaesthetics indicating that the lack of vasodilatation with methacholine or calcium ionophore was not due to a smooth muscle cell dysfunction. Thus, it appears that local anaesthetics interfere in some way with the activation of soluble guanylate cyclase.

\section{Pathophysiology}

Normal arteries provide a constant defence mechanism against intravascular thrombosis and vasoconstriction. The vasoconstricting substances that are liberated from aggregating platelets may be offset by several endothelialdependent vasodilating mechanisms leading to: (1) an increased flow to wash away and dilute the liberated substances, (2) an increased endothelial cell metabolism of those vasoactive substances, and (3) an anti-aggregation process by EDRF and PGI 2. It appears then that the vascular endothelium is a key element in maintaining a constant balance in vasomotor regulation and haemostasis.

In diseased arteries, this protective function is severely compromised (see Table III).

\section{Subarachnoid haemorrhage}

The cerebral artery vascular tone instability which occurs following subarachnoid haemorrhage is possibly related to the haemoglobin scavenging of EDRF. ${ }^{125-128}$ The experimental introduction of blood or haemoglobin into the subarachnoid space leads to vasoconstriction that persists for up to a week, ${ }^{5}$ correlating quite well with the clinical time course. The possibility also exists that local hypoxia may favour EDCF release over EDRF especially if there is an anatomical disruption of flow. ${ }^{129}$
Angioplasty
Localized coronary spasm following percutaneous trans- luminal coronary angioplasty (PTCA) is frequent. Damage and functional impairment of the endothelial cells by the catheter contribute to the local vascular instability. Expos- ing the subendothelial structure enhances platelet aggrega- tion and coronary spasm. Also, during the regeneration process the new endothelial cells are morphologically and functionally different. They show decreased receptor- mediated EDRF responsiveness, ${ }^{130-132}$ increased reac- 
tivity to vasoconstrictor agents and increased production of an endothelial-derived vasoconstricting superoxide anion. ${ }^{109}$ Over time, these cells regain full function if no untoward event disturbs their maturation. ${ }^{5}$ Cartier et al. ${ }^{133}$ demonstrated that the regenerated endothelium regained the ability to produce the contracting factor(s) first before producing the relaxing factor(s). Although these experiments were performed on rats, there is a striking crossspecies homogeneity in the endothelium-dependent physiology. These findings may provide an explanation for the propensity for vasospasm in arteries undergoing repair.

\section{Arterial and venous coronary artery bypass}

The internal mammary arteries and saphenous veins are used extensively for myocardial revascularization and long-term patency is thought to be higher for internal mammary artery than for saphenous grafts. ${ }^{134}$ Their morphological and biological characteristics may partly explain their different long-term patency. ${ }^{134-136}$ Damage to the endothelial layer, during saphenous vein harvesting, may contribute to early development of thrombosis. Platelets and an increased platelet-vessel wall interaction are important in vein graft occlusion. ${ }^{137}$ Lüscher et al. ${ }^{135}$ and Yang ${ }^{138}$ demonstrated, for the internal mammary artery graft, a greater endothelium-dependent relaxation and procyclin production after ACh, ADP, and thrombin challenge than for saphenous vein grafts. In the latter, they also established in saphenous veins that the effects of nitric oxide are reduced by endothelium-derived contracting factors originating from the cyclooxygenase pathway. Thus, reduced production of EDRF and prostacyclin, morphological differences, and greater endothelial damage in venous grafts would be in keeping with a decreased clinical longevity. Anti-platelet therapy following coronary artery bypass improves long-term venous graft patency. ${ }^{137,139,140}$ Routine probing of the internal mammary artery prior to coronary anastomosis resulted in endothelial damage and impaired vasodilatation by decreased production of EDRF and prostacyclin. ${ }^{141}$ Lastly, the gastroepiploic artery has been used as a coronary bypass conduit in a few clinical studies. O'Neil et al. ${ }^{136}$ demonstrated a higher release of vasoactive substances in vitro with the gastroepiploic artery than in the internal mammary and saphenous venous grafts which might influence the long-term patency of the gastroepiploic graft.

\section{Hypercholesterolaemia and lipid disorders}

Low-density lipoprotein (LDL) impairs EDRF activity. This impairment is probably mediated by oxidatively modified LDL (lipid peroxides and oxidized LDL). Increased plasma $\mathrm{LDL}$ activates macrophages favouring formation and deposition of oxidized LDL in the vascular wall..$^{5,142-144}$ Interestingly, when arterial segments are perfused with oxidized-LDL, an increase in the vasocon- strictive response to $\alpha$-agonist was noticed and this response was worsened if the endothelium was removed. ${ }^{145}$ This indicates that the endothelium is still able to secrete EDRF since the response is worsened in denuded arterial rings. One may speculate that the secreted EDRF is either neutralized by oxidized-LDL and/or scavenged by subendothelial macrophages (Figure 6). The increased subendothelial distance seen in atheromatosis does not appear to be a limiting factor for the diffusion of NO. ${ }^{2}$ The use of calcium antagonists was only able to block the oxidized $\mathrm{LDL}$ vasoconstriction response in denuded arterial rings. ${ }^{2}$

Dietary-induced hypercholesterolaemia has shown consistently, in coronary arteries, an impairment of endothelial-dependent relaxation with preservation of other non-endothelial-dependent vasomotor responses, i.e., $\alpha$-adrenergic response. ${ }^{146-154}$. Indeed in a primate model, this endothelial impairment is reversible with dietary manipulation. ${ }^{82}$ Patients with known coronary artery disease on a dietary programme to modify their lipoprotein profiles revealed angiographically improved endothelialdependent dilatation. ${ }^{148,155}$

\section{Coronary artery disease (CAD)}

In the absence of $\mathrm{CAD}$, intracoronary administration of $A C h$ causes vasodilatation. In contrast, patients with $C A D$ and after a heart transplant respond with a coronary constriction after $\mathrm{ACh}$ challenge. ${ }^{156-158}$ In the CAD patients, the important flow-dependent coronary dilatation is substantially impaired but can be restored. The use of nitrovasodilators of different classes is well established for therapy of angina pectoris, myocardial infarction and congestive heart failure. The modulation by the endothelium to exogenous administration of nitrates has recently been investigated. The relaxing effects of nitrovasodilators are reduced in the presence of intact endothelium compared with preparations without endothelium. This reduction in vasodilatation is directly related to endothelial release of EDRF. Restoration of full nitrovasodilatation was only possible if the intact arterial rings were pre-incubated with the EDRF inhibitor L-NMMA or when the arterial rings were denuded of their endothelium. ${ }^{159,160}$ This finding may have clinical implications in the use of nitrovasodilators to preferentially dilate those vascular segments with dysfunctional endothelial cells (unstable angina, myocardial infarction and post-CABG). Finally, nitrates have been shown to be inhibitors of endothelin production. ${ }^{161}$

\section{Hypertension}

In chronic hypertension, there are several reports of a loss or a change in endothelium-mediated functions in the peripheral arteries of humans ${ }^{146}$ and animals. ${ }^{134,162}$ The following factors were implicated in this endothelial 
dysfunction: (1) decreased release of EDRF and/or other factors (cyclooxygenase products), (2) decreased smooth muscle cell response and (3) increased release of endothelial-derived contracting factor(s). ${ }^{145,160,163}$ In the genetically spontaneous hypertensive rat, EDRF release by $\mathrm{ACh}$ was normal but there was a simultaneous release of an endothelium-derived contracting substance(s). ${ }^{164}$ In hypertensive Dahl rats, EDRF release was decreased and/or there was decreased smooth muscle cell response after ACh stimulation. ${ }^{165}$ Thus, the endothelium-dependent relaxation is impaired in the majority of hypertensive animal models. But the underlying mechanisms are different for each species. Different antihypertensive therapies, in normal rats, potentiated the endothelial relaxation to ACh challenge. ${ }^{165}$ Also, some antihypertensive agents modulated the endothelium-dependent relaxations to agonist more than others. These properties may show some therapeutic benefits in cardiovascular diseases.

\section{Diabetes mellitus}

Cardiovascular disease is a complicating feature in human diabetes mellitus. Some manifestations of cardiovascular deterioration in diabetes have been suggested to be a consequence of both morphological and functional derangements of vascular smooth muscles. Conflicting results have been reported with regard to endotheliumdependent relaxation in diabetic animals. Models of induced diabetes (streptozotocin-induced) and spontaneously diabetic rats demonstrated impaired endotheliumdependent relaxation. ${ }^{167,168}$ While no difference in endothelium-dependent peak relaxation could be detected in diabetic vessels from control, the endothelial-dependent relaxation response in diabetic vessels was more transient, i.e., returned faster to their baseline values. ${ }^{169}$ The addition of superoxide dismutase to the preparation was able to normalize the time course. The authors suggested that the subendothelial compartment of diabetic rats must have produced more oxygen-derived free radicals that could inactivate EDRF.

Another consequence of hyperglycaemia is the increased glycosylation of the amino groups of protein. One of the targeted areas is the subendothelial collagen. Because matrix collagen turnover is slow, advanced glycosylation end products accumulate in diabetes mellitus. Recently Bucala et al. ${ }^{170}$ demonstrated that these end products of glycosylation quenched EDRF. These results implicate advanced glycosylation products as important modulators of nitric oxide activity and endothelium-dependent relaxation.

\section{Septic shock}

In animals, agonist-induced NO released from vascular endothelium leads to peripheral vasodilatation, a decrease in blood pressure and tachycardia, but these effects are short-lived and vascular tone returns to normal once the agonist is terminated. This agonist is able to activate the calcium-dependent NO synthase enzyme only for the duration of exposure. Recently cultured endothelial cells from porcine aorta express a second, distinct, inducible calcium-independent NO synthase in response to bacterial lipopolysaccharide endotoxin. ${ }^{171}$ Once induced, NO synthesis is released continuously for several hours without further stimulation. This inducible NO synthase is reported to be present also in activated macrophage. ${ }^{172}$

Not only may cultured endothelial cells but also vascular rings incubated with endotoxin or cytokines lead to induction of NO synthase with progressive relaxation and a decreased vasoconstrictor response. ${ }^{173,174}$ Only LNMMA can reverse the effects of endotoxin-induced NO synthase, thus establishing NO as the mediator of vasodilatation. Therapeutic intervention with the use of NO inhibitor has already been applied in two patients with severe septic shock. ${ }^{175}$ The patients selected were those who had not responded to conventional therapy and were thought unlikely to survive. Intravenous administration of L-NMMA had an immediate $(<2)$ but short-lived $(<15$ $\mathrm{min}$ ) increase in systemic blood pressure.

Interestingly, previous incubation with glucocorticoids inhibited NO synthase induction by endotoxins and the resulting vascular relaxation. If glucocorticoids are added to the preparation after the induction of NO synthase by endotoxins, it will have no effect upon the continuous synthesis of NO. ${ }^{171}$

Thus, endotoxins or cytokines induce a distinct calciumindependent NO synthase which may explain the observed vasodilatation in endotoxaemia. Furthermore, the glucocorticoid findings may help explain the discrepancy concerning their clinical benefits when used in septic shock.

\section{Conclusion}

The endothelial cell should be regarded as a highly active metabolic and endocrine organ interacting with the circulating cells. Many pathophysiological conditions (atheromatosis, hypertension, balloon angioplasty causing denudation, and endothelial impairment following heart transplantation) interfere in this well orchestrated vascular balance. New knowledge of the underlying mechanisms in the endothelial-dependent vasomotor control gives us a greater understanding of the many pathophysiological processes and may help us to develop new therapeutic modalities yielding greater clinical benefit.

\section{Acknowledgment}

The authors are in debt to the following: Pierrette Thivierge, Christiane Lussier and Mary Morello, for their excellent secretarial work, as well as Charles Dupont for the excellent graphics. 


\section{References}

1 Bassenge E, Huckstorf $\mathrm{CH}$. Endothelium-mediated control of coronary circulation. Acta Cardiol 1991a; XLVI: 419-24.

2 Bassenge E, Heusch G. Endothelial and neuro-humoral control of coronary blood flow in health and disease. Physiol Biochem Pharmacol 1990; 116: 77-165.

3 Bassenge E, Busse R. Endothelial modulation of coronary tone. Prog Cardiovasc Dis 1988; 30: 349-80.

4 Vrints $C$, Herman AG. Role of the endothelium in the regulation of coronary artery tone. Acta Cardiol 1991; XLVI: $399-418$.

5 Henderson AH. Endothelium in control. Br Heart J 1991; 65: 116-25.

6 Dinh Xuan AT, Higenbottam TW. Non-prostanoid endothelium-derived vasoactive factors. J Intern Med Res 1989; 17: 305-15.

7 Husain M, Moss J. Endothelium-dependent vascular smooth muscle control. Journal of Clinical Anesthesia 1988; 1 : 135-45.

8 Ignarro $L$, Byrns RE, Buga GM, Wood KS. Endotheliumderived relaxing factor from pulmonary artery and vein possesses pharmacologic and chemical properties identical to those of nitric oxide radical. Circ Res $1987 ; 61: 866-79$.

9 Furchgott RF. Role of endothelium in responses of vascular smooth muscle. Circ Res 1983; 53: 557-73.

10 Furchgott $R F$, Vanhoutte $P M$. Endothelium-derived relaxing and contracting factors. Faseb J 1989; 3: 2007-18.

11 Altura BM. Endothelium-dependent relaxation and the reticuloendothelial system. In: Vanhoutte PM (Ed.). Vasodilatation: Vascular Smooth Muscle, Peptides, Autonomic Nerves, and Endothelium. New York: Raven Press Ltd., 1988: 503-10.

12 Marcus AJ. Thrombosis and inflammation as multicellular processes: pathophysiologic significance of transcellular metabolism. Blood 1990; 76: 1903-7.

13 Johns RA. Endothelium-derived relaxing factor: basic review and clinical implications. Journal of Cardiothoracic and Vascular Anesthesiology 1991; 5: 69-79.

14 Förstermann U, Mügge A, Alheid U, Haverich A, Frëlich $J C$. Selective attenuation of endothelium-mediated vasodilation in atherosclerotic human coronary arteries. Circ Res 1988a; 62: 185-90.

15 Furchgort RF, Zawadzki JV. The obligatory role of endothelial cells in the relaxation of arterial smooth muscle by acetylcholine. Nature 1980; 288: 373-6.

16 Griffith TM, Edwards DH, Lewis MJ, Newby AC, Henderson $A H$. The nature of endothelium-derived vascular relaxant factor. Nature 1984; 308: 645-7.

17 Griffith TM, Henderson AH. EDRF and the regulation of vascular tone. Int J Microcirc Clin Exp 1989; 8: 383-96.

18 Omar HA, Cherry PD, Mortelliti MP, Burke-Wolin T, Wolin MS. Inhibition of coronary artery superoxide dismutase attenuates endothelium-dependent and -inde- pendent nitrovasodilatator relaxation. Circ Res 1991; 69: 601-8.

19 Glover WE, Marks RM, Petrenas GG. Evidence for the release of a vascular relaxing factor from cultured human endothelial cells. In: Vanhoutte PM (Ed.). Vasodilation: Vascular Smooth Muscle, Peptides, Autonomic Nerves, and Endothelium. New York: Raven Press, Ltd., 1988: 421-5.

20 Ignarro LJ, Byrns RE, Wood KS. Biochemical and pharmacological properties of endothelium-derived relaxing factor and its similarity to nitric oxide radical. In: Vanhoutte PM (Ed.). Vasodilation: Vascular Smooth Muscle, Peptides, Autonomic Nerves, and Endothelium. New York: Raven Press, Ltd., 1988: 427-35.

21 Palmer RMJ, Ferrige AG, Moncada S. Nitric oxide release accounts for the biological activity of endotheliumderived relaxing factor. Nature 1987; 327: 524-6.

22 Palmer RMJ, Ashton DS, Moncada S. Vascular endothelial cells synthesize nitric oxide from $\mathrm{L}$-arginine. Nature 1988; 333: 664-6.

23 Bredt DS, Snyder $S H$. Isolation of nitric oxide synthetase, a calmodulin-requiring enzyme. Proc Natl Acad Sci 1990; 87: 682-5.

24 Myers PR, Minor RL, Guerra R Jr, Bates JN, Harrison $D G$. Vasorelaxant properties of the endothelium-derived relaxing factor more closely resemble S-nitrosocysteine than nitric oxide. Nature 1990; 345: 161-3.

25 Sembowicz A, Hecker M, MacArthur H, Sessa WC, Vane $J R$. Nitric oxide and another potent vasodilator are formed from $N^{G}$-hydroxy-L-arginine by cultured endothelial cells. Proc Natl Acad Sci 1991; 88: 11172-6.

26 Gruetter CA, Gruetter DY, Lyon JE, Kadowitz PJ, Ignarro $J$. Relationship between cyclic guanosine $3^{\prime}: 5^{\prime}$-monophosphate formation and relaxation of coronary arterial smooth muscle by glyceryl trinitrate, nitroprusside, nitrite and nitric oxide: effects of methylene blue and methemoglobin. J Pharmacol Exp Ther 1981; 219: 181-6.

27 Ignarro L, Burke TM, Wood KS, Wolin MS, Kadowitz $P J$. Association between cyclic GMP accumulation and acetylcholine-elicited relaxation of bovine intrapulmonary artery. J Pharmacol Exp Ther 1983; 228: 682-90.

28 Kaley G, Messina EJ, Wolin MS. Endothelium-derived relaxing factors and cyclic GMP in the microcirculation. In: Vanhoutte PM (Ed.). Vasodilation: Vascular Smooth Muscle, Peptides, Autonomic Nerves, and Endothelium. New York: Raven Press, Ltd., 1988: 497-502.

29 Murad F. Cyclic guanosine monophosphate as a mediator of vasodilation. J Clin Invest 1986; 78: 1-5.

30 Feletou $M$, Vanhoutte $P M$. Endothelium-dependent hyperpolarization of canine coronary smooth muscle. $\mathrm{Br} \mathrm{J}$ Pharmacol 1988; 93: 515-24.

31 Bassenge $E$. Flow-dependent regulation of coronary vasomotor tone. Eur Heart J (Suppl F) 1989; 10: 22-7.

32 Benyó Z, Kiss G, Szabó C, Csáki C, Kovach AGB. Import- 
ance of basal nitric oxide synthesis in regulation of myocardial blood flow. Cardiovasc Res 1991; 25: 700-3.

33 Busse R, Trogisch G, Bassenge $E$. The role of endothelium in the control of vascular tone. Bas Res Cardiol 1985; 80: 475-90.

34 Collier J, Vallance $P$. Endothelium-derived relaxing factor is an endogenous vasodilator in man. $\mathrm{Br} J$ Pharmacol 1989; 97: 639-41.

35 Drexler $H$, Zeiher AM, Wollschlager H, Meinertz T, Just $H$, Bonzel $T$. Flow-dependent coronary artery dilatation in humans. Circulation 1989; 80: 466-74.

36 Harder DR. Pressure-induced myogenic activation of cat cerebral arteries is dependent on intact endothelium. Circ Res 1987; 60: 102-7.

37 Holtz J, Förstermann U, Pohl U, Giesler M, Bassenge E. Flow-dependent, endothelium-mediated dilation of epicardial coronary arteries in conscious dogs: effects of cyclooxygenase inhibition. J Cardiovasc Pharmarcol 1984; 6: 1161-9.

38 Chu A, Chambers DE, Lin CC, Kuehl WD, Cobb FR. Nitric oxide modulates epicardial coronary basal vasomotor tone in awake dogs. Am J Physiol 1990; 258: H1250-H1254.

39 Aisaka K, Gross SS, Griffith OW, Levi R. $\mathrm{N}^{\mathrm{G}}$-Methylarginine, an inhibitor of endothelium-derived nitric oxide synthesis, is a potent pressor agent in the guinea pig: does nitric oxide regulate blood pressure in vivo? Biochem Biophys Res Comm 1989; 160: 881-6.

$40 \mathrm{Chu}$ A, Cobb FR. Vasoactive effects of serotonin on proximal coronary arteries in awake dogs. Circ Res (Suppl II) 1987; II-8 I-II-87.

41 Griffith $T M$, Lewis $M J$, Newby $A C$, Henderson $A H$. Endothelium-derived relaxing factor. J Am Coll Cardiol 1988; 12: 797-806.

42 Angus JA, Campbell GR, Cocks TM, Manderson JA. Vasodilatation by acetylcholine is endothelium-dependent: a study by sonomicrometry in canine femoral artery in vivo. J Physiol 1983; 344: 209-22.

43 Bhardwaj $R$, Moore PK. Endothelium-derived relaxing factor and the effects of acetylcholine and histamine on resistance blood vessels. $\mathrm{Br} J$ Pharmacol 1988; 95 : 835-43.

44 Ignarro LJ, Harbison RG, Wood K, Kadowitz PJ. Activation of purified soluble guanylate cyclase by endotheliumderived relaxing factor from intrapulmonary artery and vein: stimulation by acetylcholine, bradykinin and arachidonic acid. J Pharmacol Exp Ther 1986; 237: 893-900.

45 Komori K, Suzuki $H$. Heterogeneous distribution of muscarinic receptors in the rabbit saphenous artery. $\mathrm{Br} J$ Pharmacol 1987a; 92: 657-64.

46 Komori K, Suzuki H. Electrical responses of smooth muscle cells during cholinergic vasodilation in the rabbit saphenous artery. Circ Res 1987b; 61: 586-93.

47 Knight DR, Shen YT, Young MA, Vatner SF. Acetylcho- line-induced coronary vasoconstriction and vasodilation in tranquilized baboons. Circ Res 1991; 69: 706-13.

48 Stephenson JA, Gibson RE, Summers RJ. An autoradiographic study of muscarinic cholinoceptors in blood vessels: no localization on vascular endothelium. Eur J Pharmacol 1988; 153: 271-83.

49 Burnstock $G$. The changing face of autonomic neurotransmission. Acta Physiol Scand 1986; 126: 67-91.

50 Burnstock $G$, Warland JJI. $\mathrm{P}_{2}$-purinoceptors of two subtypes in the rabbit mesenteric artery: reactive blue 2 selectively inhibits responses mediated via the $P 2 y$ - but not the P2x-purinoceptor. Br J Pharmacol 1987; 90: 383-91.

51 Burnstock $G$, Lincoln J, Feher E, et al. Serotonin is localized in endothelial cells of coronary arteries and released during hypoxia: a possible new mechanism for hypoxiainduced vasodilatation of the rat heart. Experientia 1988; 44: 705-7.

52 Burnstock $G$. Vascular control by purines with emphasis on the coronary system. Eur Heart J (Suppl F) 1989; 10: 15-21.

53 Holtz J, Held W, Sommer $O$, Küne G, Bassenge E. Ergonovine-induced constrictions of epicardial coronary arteries in conscious dogs: a-adrenoceptors are not involved. Basic Res Cardiol 1982; 77: 278-91.

54 Vidal MJ, Romero JC, Vanhoutte PM. Endotheliumderived relaxing factor inhibits renin release. Eur J Pharmacol 1988; 149; 401-2.

55 Olesen $S P$, Chapham $D E$, Davies $P F$. Haemodynamic shear stress activates a $\mathrm{K}^{+}$current in vascular endothelial cells. Nature 1988; 331: 168-70.

56 Cooke JP, Rossitch E, Andon NA, Loscalzo J, Dzau VJ. Flow activates an endothelial potassium channel to release an endogenous nitrovasodilator. J Clin Invest 1991; 88 : 1663-71.

57 Pohl U, Busse R, Bassenge E. Endothelial cell as oxygen sensor. In: Vanhoutte PM (Ed.). Vasodilatation: Vascular Smooth Muscle, Peptides, Autonomic Nerves, and Endothelium. New York: Raven Press, Ltd., 1988: 483-8.

58 De Mey JG, Vanhoutte PM. Anoxia and endotheliumdependent reactivity of the canine femoral artery. J Physiol 1983; 335: 65-74.

59 Lombard JH, Harder DR, Stekiel WJ. Hypoxic vasodilatation and hypertension. In: Vanhoutte PM (Ed.).

Vasodilatation: Vascular Smooth Muscle, Peptides, Autonomic Nerves, and Endothelium. New York: Raven Press, Ltd., 1988: 61-4.

60 Kourembanas S, Marsden PA, McQuillan LP, Faller DV. Hypoxia induces endothelin gene expression and secretion in cultured human endothelium. J Clin Invest 1991; 88: 1054-7.

61 Reilly WM, Saville VL, Burnstock G. An assessment of the antagonist activity of reactive Blue 2 at $P$ - and $P_{2}$ purinoceptors: supporting evidence for purinergic 
innervation of the rabbit portal vein. Eur J Pharmacol 1987; 140; 47-53.

62 Shimada SG, Stitt JT. An analysis of the purinergic component of active muscle vasodilation obtained by electrical stimulation of the hypothalamus in rabbits. Br J Pharmacol 1984; 83: 577-89.

63 Koller A, Kaley G. Role of endothelium in reactive dilation of skeletal muscle arterioles. Am J Physiol 1990; 259: H1313-H1316.

64 Inoue T, Kandan MS. Noradrenergic and noncholingergic excitatory neurotransmission in rat intrapulmonary artery. Am J Physiol 1988; 254: 1142-8.

65 Burnstock $G$. Purinergic receptors in the heart. Circ Res (Suppl I) 1986; A5-82.

66 Leusen I, Van de Voorde J. Endothelium-dependent responses to histamine. In: Vanhoutte PM (Ed.). Vasodilatation: Vascular Smooth Muscle, Peptides, Autonomic Nerves, and Endothelium. New York: Raven Press, Ltd., 1988: 469-74.

67 Toda $N$. Heterogeneous responses to histamine in blood vessels. In: Vanhoutte PM (Ed.). Vasodilatation: Vascular Smooth Muscle, Peptides, Autonomic Nerves, and Endothelium. New York: Raven Press, Ltd., 1988: 531-5.

68 Tozzi CA, Dorrell S, Merrill GF. Evidence of histamineinduced myocardial ischaemia: reversal by chlorpheneramine and potentiation by atherosclerosis. Cardiovasc Res 1985; 19: 744-53.

69 Kalsner $S$, Richards $R$. Coronary arteries of cardiac patients are hyperactive and contain stores of amines. A mechanism for coronary spasm. Science $1984 ; 223$ : 1435-7.

70 Tsuru $H$. Heterogeneity of the vascular effects of bradykinin. In: Vanhoutte PM (Ed.). Vasodilatation: Vascular Smooth Muscle, Peptides, Autonomic Nerves, and Endothelium. New York: Raven Press, Ltd., 1988: 479-82.

71 Cheng PD, Furchgott RF, Zawadzki JV, Jothianandan D. Role of the endothelial cells in relaxation of isolated arteries by bradykinine. Proc Natl Acad Sci USA 1982; 79: 2106-10.

72 Förstermann $U$, Hertting $G$, Neufang $B$. The role of the endothelial and non-endothelial prostaglandines in the relaxation of isolated blood vessels of the rabbit induced by acetylcholine and bradykinines. Br J Pharmacol 1986; 87: 521-32.

73 Richard V. Tanner FC. Different activation of L-arginine pathway by bradykinin, serotonin, and clonidine in coronary arteries. Am J Physiol 1990; H1433-H1439.

74 Bassenge $E$. Antiplatelet effects of endothelium-derived relaxing factor and nitric oxide donors. Eur Heart J (Suppl E) $1991 \mathrm{~b} ; 12: 12-5$.

75 Yang $Z$, Stulz $P$, von Segesser $L$, et al. Different interactions of platelets with arterial and venous coronary bypass vessels. Lancet 1991; 337: 939-43.
76 Marcus AJ, Safier LB, Hajjar KA. Inhibition of platelet function by an aspirin-insensitive endothelial cell ADPase. J Clin Invest 1991; 88: 1690-6.

77 Cohen RA. Platelet-derived serotonin and the vascular wall. In: Vanhoutte PM (Ed.). Vasodilatation: Vascular Smooth Muscle, Peptides, Autonomic Nerves, and Endothelium. New York: Raven Press, Ltd., 1988: 243-7.

78 Dole WP, Lamping KG, Marcus ML. Endothelium and responses of large coronary arteries to serotonin in vivo. In: Vanhoutte PM (Ed.). Vasodilatation: Vascular Smooth Muscle, Peptides, Autonomic Nerves, and Endothelium. New York: Raven Press, Ltd., 1988: 537-42.

79 Houston DS, Vanhoutte PM. Comparison of serotonergic receptor subtypes on the smooth muscle and endothelium of the canine coronary artery. J Pharmacol Exp Ther 1987; 244: 1-10.

80 Vanhoutte PM. Cardiovascular effects of serotonin. J Cardiovasc Pharmacol 1987; 10: S8-S11.

81 Vanhoutte PM. Could the absence or malfunction of vascular endothelium precipitate the occurrence of vasospasm? J Mol Cell Cardiol 1986; 18: 679-89.

82 Heistad DD, Mark AL, Marcus ML, Piegors DJ, Armstrong ML. Dietary treatment of atherosclerosis abolishes hyperresponsiveness to serotonin: implications for vasospasm. Circ Res 1987; 61: 346-51.

83 Lopez JAG, Armstrong ML, Piegors DJ, Heistad DD. Effect of early and advanced atherosclerosis on vascular responses to serotonin, thromboxane $A_{2}$, and ADP. Circulation 1989; 79: 698-705.

84 Freiman PC, Mitchell GG, Heistad DD, Armstrong ML Harrison DG. Atherosclerosis impairs endotheliumdependent vascular relaxation to acetylcholine and thrombin in primates. Circ Res 1986; 58: 783-9.

85 Lüscher TF. Endothelium-derived nitric oxide: the endogenous nitrovasodilator in the human cardiovascular system. Eur Heart J (Suppl E) 1991; 12: 2-11.

86 De Mey JG. Atrial natriuretic peptides and blood pressure. In: Vanhoutte PM (Ed.). Vasodilatation: Vascular Smooth Muscle, Peptides, Autonomic Nerves, and Endothelium. New York: Raven Press, Ltd., 1988: 123-8.

87 Ohlstein EH, Berkowitz BA. Atrial natriuretic factor and production of cyclic GMP. In: Vanhoutte PM (Ed.). Vasodilatation: Vascular Smooth Muscle, Peptides, Autonomic Nerves, and Endothelium. New York: Raven Press, Ltd., 1988: 113-7.

88 Bolli P, Mueller B, Raine AE, et al. Vascular effects of atrial natriuretic peptides. In: Vanhoutte PM (Ed.). Vasodilatation: Vascular Smooth Muscle, Peptides, Autonomic Nerves, and Endothelium. New York: Raven Press, Ltd., 1988: 129-35.

89 Brain SD, Williams TJ, Tippins JR, Morris HR, MacIntyre I. Calcitonin generelated peptide is a potent vasodilator. Nature 1985; 313: 54-6. 
90 Weike E, Reinecke M, Opherk D, Forsmann WG. Peptidergic innervation (Substance $P$ ) in human heart. $J$ Mol Cell Cardiol 1981; $13: 331-3$.

91 Marshall 1, Craig RK. The cardiovascular effects and mechanism of action of the calcitonin gene-related peptides. In: Vanhoutte PM (Ed.). Vasodilatation: Vascular Smooth Muscle, Peptides, Autonomic Nerves, and Endothelium. New York: Raven Press, Ltd., 1988: 81-7.

92 Schachter M, Thom S, Hughes A, Martin G, Goldberg P, Sever $P$. Calcitonin gene-related peptide: vasodilator responses in the human vasculature. In: Vanhoutte PM (Ed.). Vasodilatation: Vascular Smooth Muscle, Peptides, Autonomic Nerves, and Endothelium, New York: Raven Press, Lid., 1988: 475-8.

93 Nakamura Y, Parent R, Lavallée $M$. Disparate effects of substance $P$ on systemic and coronary beds in conscious dogs. Circulation 1991; 84: 300-12.

94 Vane JR, Anggard EE, Botting RM. Regulatory functions of the vascular endothelium. N Engl J Med 1990; 323: 27-36.

95 Nagao T, Vanhoutte PM. Hyperpolarization contributes to endothelium-dependent relaxations to acetylcholine in femoral veins of rats. Am J Physiol 1991; H1034-H1037.

96 Rubanyi GM, Vanhoutte $P M$. Nature of endotheliumderived relaxing factor: are there two relaxing mediators? Circ Res (Suppl II) 1987; 61: II-61-II-67:

97 Rubanyi GM, Vanhoutte PM. Polarized release of endothelium-derived relaxing factor(s) by melittin in canine femoral arteries. In: Vanhoutte PM (Ed.). Vasodilatation: Vascular Smooth Muscle, Peptides, Autonomic Nerves, and Endothelium. New York: Raven Press, Ltd., 1988: 489-95.

98 Clozel $M$, Fischli $W$. Human cultured endothelial cells do secrete endothelin-1. J Cardiovasc Pharm (Suppl 5) 1989; S229-S231.

99 Gillespie MN, Owasoyo JO, McMurtry IF, O'Brien RF. Sustained coronary vasoconstriction provoked by a peptidergic substance released from endothelial cells in culture. J Pharmacol Exp Ther 1985; 236: 339-43.

100 Boulanger $C$, Luischer TF. Release of endothelin from the porcine aorta. J Clin Invest 1990; 85: 587-90.

101 Yanagisawa M, Kurihara H, Kimura S, et al. A novel potent vasoconstrictor peptide produced by vascular endothelial cells. Nature 1988; 332: 411-5.

102 Yanagisawa M, Masaki T. Molecular biology and biochemistry of the endothelins. TIPS 1989a; 10: 374-8.

103 Yanagisawa M, Masaki T. Endothelin, a novel endothelium-derived peptide. Biochem Pharmacol 1989b; 38: 1877-83.

104 Inoue A, Yanagisawa M, Kimura S, et al. The human endothelin family: three structurally and pharmacologically distinct isopeptides predicted by three separate genes. Proc Natl Acad Sci USA 1989; 86: 2863-7.
105 Cernacek $P$, Stewart DJ. Immunoreactive endothelin in human plasma: marked elevations in patients in cardiogenic shock. Biochem Biophys Res Comm 1989; 161: $562-7$.

106 Pohl U, Busse R. Endothelium-dependent modulation of vascular tone and platelet function. Eur Heart J (Suppl B) 1990; 1I: 35-42.

107 Bunchman TE, Brookshire CA. Cyclosporine-induced synthesis of endothelin by cultured human endothelial cells. J Clin Invest 1991; 88: 310-14.

108 Ohlstein EH, Storer BL, Butcher JA, Debouck C, Feuerstein $G$. Platelets stimulate expression of endothelin mRNA and endothelium biosynthesis in cultured endothelial cells. Circ Res 1991; 69: 832-41.

109 Suzuki S, Kujikuri J, Suzuki A, Itoh T. Effects of endothelin-1 on endothelial cells in the porcine coronary artery. Circ Res 1991; 69: 1361-8.

110 Thiemermann C, Lidbury PL, Thomas R, Vane J. Endothelin inhibits $e x$ vivo platelet aggregation in the rabbit. Eur J Pharmacol 1988; 158: 181-2.

111 Lin PJ, Pearson PJ, Cartier R, Schaff HV. Superoxide anion mediates the endothelium-dependent contractions to serotonin by regenerated endothelium. J Thorac Cardiovasc Surg 1991; 102: 378-85.

112 Blaise G, Sill JC, Nugent M, Van Dyke RA, Vanhoutte $P M$. Isoflurane causes endothelium-dependent inhibition of contractile responses of canine coronary arteries. Anesthesiology 1987; 67: 513-7.

113 Bollen BA, Tinker JH, Hermsmeyer $K$. Halothane relaxes previously constricted isolated porcine coronary artery segments more than isoflurane. Anesthesiology 1987; 66: 748-52.

114 Muldoon SM, Hart JL, Bowen KA, Freas W. Attenuation of endothelium-mediated vasodilation by halothane. Anesthesiology 1988; 68: 31-7.

115 Stone DJ, Johns RA. Endothelium-dependent effects of halothane, enflurane, and isoflurane on isolated rat aortic vascular rings. Anesthesiology 1989; 71: 126-32.

116 Witzeling TM, Sill JC, Hughes JM, Blaise GA, Nugent M, Rorie $D K$. Isoflurane and halothane attenuate coronary artery constriction evoked by serotonin in isolated porcine vessels and in intact pigs. Anesthesiology 1990; 73 : 100-8.

117 Greenblatt EP, Loeb $A L$, Longnecker $D E$. Influences of halothane and isoflurane on endothelium-dependent. circulatory control in vivo. Anesthesiology 1991; 75: A531.

118 Pettis MS, Sill JC, Bertha B, Witzeling T, Rorie J. Nitrous oxide and coronary artery constriction in pigs. Anesthesiology 1990; 73: A553.

119 Fratacci $M D$,. Frostell CG, Chen TY, Wain JC, Robinson $D R$, Zapol WM. Inhaled nitric oxide. A selective pulmonary vasodilator of heparin-protamine vasoconstriction in sheep. Anesthesiology 1991; 75: 990-9. 
120 Chang KSK, Lacy MO, Davis RF. Propofol produces endothelium-independent vasodilation and may act as a calcium channel blocker. Anesthesiology 1991; 75: A536.

121 Ozhan M, Sill JC, Katusic Z, Rorie D, Uhl C. Propofol, thiopental and contractile responses in isolated pig coronary arteries and cultured vascular smooth muscle cells. Anesthesiology 1991; 73: A583.

122 Dozaki S, Chang KSK, Davis RF. Etomidate produces vasodilation by mixed endothelium-dependent and independent mechanisms. Anesthesiology 1991; 75: A537.

123 Blaise GA, Witzeling TM, Sill JC, Vinay $P$, Vanhoutte $P M$. Fentanyl is devoid of major effects on coronary vasoreactivity and myocardial metabolism in experimental animals. Anesthesiology 1990; 72: 535-41.

124 Johns RA. Local anesthetics inhibit endothelium-dependent vasodilation. Anesthesiology 1989; 70: 805-11.

125 Kassel NF, Sasaki T, Colohan ART, Nazar G. Cerebral vasospasm following aneurysmal subarachnoid hemorthage. Stroke 1985; 16: 562-72.

126 Nakagomi T, Kassel NF, Sasaki T, Fujiwara S, Lehman $R M$, Torner JC. Impairment of endothelium-dependent vasodilation induced by acetylcholine and adenosine triphosphate following experimental subarachnoid hemorrhage. Stroke 1987; 18: 482-9.

127 Kanamaru K, Waga S, Kojima T, Fujimoto K, Niwa S. Endothelium-dependent relaxation in canine basilar arteries. Stroke 1987; 18: 938-43.

128 Byrne JV, Griffith TM, Edwards DH, Harrison TJ, Johnston $K R$. Investigation of the vasoconstrictor action of subarachnoid haemoglobin in the pig cerebral circulation in vivo. Br J Pharmacol 1989; 97: 669-74.

129 Rubanyi GM, Vanhoutte PM. Hypoxia releases a vasoconstrictor substance from the canine vascular endothelium. J Physiol 1985; 364: 45-56.

130 Fischell TA, Nellessen $U$. Endothelium-dependent arterial vasoconstriction after balloon angioplasty. Circulation 1989; 79: 899-910.

131 Fischell TA, Bausback $K N$, McDonald TV. Evidence for altered epicardial coronary artery autoregulation as a cause of distal coronary vasoconstriction after successful percutaneous transluminal coronary angioplasty. J Clin Invest 1990; 86: 575-84.

132 Guerra R, Brotherton AFA, Goodwin PJ, Clark CR, Armstrong $M L$, Harrison DG. Mechanisms of abnormal endothelium-dependent vascular relaxation in atherosclerosis: implications for altered autocrine and paracrine functions of EDRF. Blood Vessels 1989; 26: 300-14.

133 Cartier R, Pearson PJ, Lin PJ, Schaff HV. Time course and extent of recovery of endothelium-dependent contractions and relaxations after direct arterial injury. $J$ Thorac Cardiovasc Surg 1991; 102: 371-7.
134 Lüscher TF, Yang Z, Diederich D, Bühler FR. Endothelium-derived vasoactive substances: potential role in hypertension, atherosclerosis, and vascular occlusion. $\mathrm{J}$ Cardiovasc Pharmacol (Suppl 6) 1989; 14: S63-S69.

135 Lüscher $T F$, Diederich D, Siebenmann $R$, et al. Difference between endothelium-dependent relaxation in arterial and in venous coronary bypass grafts. $\mathrm{N}$ Engl $\mathrm{J}$ Med 1988; 319: 462-7.

136 O'Neil GS, Chester AH, Allen SP, et al. Endothelial function of human gastroepiploic artery. J Thorac Cardiovasc Surg 1991; 102: 561-5.

137 Fuster V, Chesebro JH. Role of platelets and platelet inhibitors in aortocoronary artery vein-graft disease. Circulation 1986; 73:2: 227-32.

138 Yang $Z$, von Segesser $L$, Bauer $E$, et al. Different activation of the endothelial L-Arginine and cyclooxygenase pathway in the human internal mammary artery and saphenous vein. Circ Res 1991; 68: 52-60.

139 Chesebro JH, Fuster V, Elveback LR, et al. Effect of dipyridamole and aspirin on late vein-graft patency after coronary bypass operations. N Engl J Med 1984; 310: 209-14.

140 Chesebro JH, Clements IP, Fuster V, et al. A plateletinhibitor-drug trial in coronary-artery bypass operations N Engl J Med 1982; 307: 73-8.

141 Johns RA, Peach MJ, Flanagan T, Kron IL. Probing of the canine mammary artery damages endothelium and impairs vasodilation resulting from prostacyclin and endothelium-derived relaxing factor. J Thorac Cardiovasc Surg 1989; 97: 252-8.

142 Jacob M, Plane F, Bruckdorfer KR. Native and oxidized low-density lipoproteins have different inhibitory effects on endothelium-derived relaxing factor in the rabbit aorta. Br J Pharmacol 1990; 100: 21-6.

143 Howes LG, Krum H. Plasma lipoproteins, cardiovascular reactivity and the sympathetic nervous system. J Auton Pharmac 1989; 9: 293-301.

144 Chin JH, Azhar S, Hoffman BB. Inactivation of endothelial-derived relaxing factor by oxidized lipoproteins. J Clin Invest 1992; 89: 10-18.

$145 W u C C, B o h r D F$. Role of endothelium in the response to endothelin in hypertension. Hypertension 1990; 16: 677-81.

146 Creager MA, Cooke JP, Mendelsohn ME, et al. Impaired vasodilation of forearm resistance vessels in hypercholesterolemic humans. J Clin Invest 1990; 86: 228-34.

147 Harrison DG, Armstrong ML, Freiman PC, Heistad DD. Restoration of endothelium-dependent relaxation by dietary treatment of atherosclerosis. J Clin Invest 1987a; 80: 1808-11.

148 Harrison DG, Freiman PC, Armstrong ML, Marcus $M L$, Heistad DD. Alterations of vascular reactivity in atherosclerosis. Circ Res (Suppl II) 1987b; 61: II74-II80. 
149 Harrison DG. Atherosclerosis alters endothelium-dependent responses to a variety of neurohumoral agents: potential mechanisms and pathophysiologic consequences. In: Vanhoutte PM (Ed.). Vasodilatation: Vascular Smooth Muscle, Peptides, Autonomic Nerves, and Endothelium. New York: Raven Press, Ltd., 1988: 517-21.

150 Heistad DD, Armstrong ML, Marcus ML, Piegors DJ, Mark $A L$. Augmented responses to vasoconstrictor stimuli in hypercholesterolemic and atherosclerotic monkeys. Circ Res 1984; 54: 711-8.

151 Verbeuren TJ, Herman AG. Endothelium-dependent relaxations are inhibited in atherosclerotic blood vessels. In: Vanhoutte PM (Ed.). Vasodilatation: Vascular Smooth Muscle, Peptides, Autonomic Nerves, and Endothelium. New York: Raven Press, Ltd., 1988: 511-5.

152 Osborne JA, Siegman MJ, Sedar AW, Mooers SU, Lefer $A M$. Lack of endothelium-dependent relaxation in coronary resistance arteries of cholesterol-fed rabbits. Am J Physiol 1989; 256: C591-C597.

153 Ganz P, Ludmer PL, Leopold JA, et al. Endothelial dysfunction in vivo: studies in animals and in patients with coronary atherosclerosis. In: Vanhoutte PM (Ed.). Vasodilatation: Vascular Smooth Muscle, Peptides, Autonomic Nerves, and Endothelium. New York: Raven Press, Ltd., 1988: 543-9.

154 Drexler $H$, Zeiher AM, Wollschlager $H$, Just $H$. Selective endothelial dysfunction in patients with hypercholesterolemia and angiographically normal coronary arteries. J Am Coll Cardiol 1990; 15: 158A.

155 Vekshtein VI, Yeung AC, Vita JA, et al. Fish oil improves endothelium-dependent relaxation in patients with coronary artery disease. Circulation (Suppl II) 1989; 80: II -434 .

156 Ludmer PL, Selwyn AP, Shook TL, et al. Paradoxical vasoconstriction induced by acetylcholine in atherosclerotic coronary arteries. N Engl J Med 1986; 315: 1046-51.

157 Werns SW, Walton JA, Hsia HH, Nabel EG, Sanz ML, $P$ itt $B$. Evidence of endothelial dysfunction in angiographically normal coronary arteries of patients with coronary artery disease. Circ Res 1989; 79: 287-91.

158 Nellessen U, Lee TC, Fischell TA. Effects of acetylcholine on epicardial coronary arteries after cardiac transplantation without angiographic evidence of fixed graft narrowing. Am J Cardiol 1988; 62: 1093-7.

159 Pohl U, Busse R. Endothelium-derived relaxant factor inhibits effects of nitrocompounds in isolated arteries. Am J Physiol 1987; 252: H307-H313.

160 Diederich D, Yang Z, Bühler FR, Lüscher TF. Impaired endothelium-dependent relaxations in hypertensive resistance arteries involve cyclooxygenase pathway. Am J Physiol 1990; 258: H445-H451.
161 Boulanger $C M$, Lüscher $T F$. Hirudin and nitrates inhibit the thrombin-induced release of endothelin from the intact porcine aorta. Circ Res 1991; 68: 1768-72.

162 Lücher TF, Vanhoutte PM. Hypertension and endothelium-dependent responses. In: Vanhoutte PM (Ed.). Vasodilatation: Vascular Smooth Muscle, Peptides, Autonomic Nerves, and Endothelium. New York: Raven Press, Ltd., 1988: 523-9.

163 Auch-Schwelk W, Vanhoutte PM. Endothelium-derived contracting factor released by serotonin in the aorta of the spontaneously hypertensive rat. Am J Hypertens 1991; 4: 769-72.

164 Lüscher TF, Vanhoutte PM. Endothelium-dependent contractions to acetylcholine in the aorta of the spontaneously hypertensive rat. Hypertension 1986; 8: 344-8.

165 Lüscher TF, Raij L, Vanhoutte PM. Endothelium dependent vascular responses in normotensive and hypertensive dahl rats. Hypertension 1987; 9: 157-63.

166 Shultz PJ, Raij $L$. Effects of antihypertensive agents on endothelium-dependent and endothelium-independent relaxations. Br J Clin Pharmacol 1989; 28: 151S-157S.

167 Durante W, Sen AK, Suahara FA. Impairment of endothelium-dependent relaxation in aortae from spontaneously diabetic rats. Br J Pharmacol 1988; 94: 463-8.

168 Pieper GM, Gross GJ. Oxygen free radicals abolish endothelium-dependent relaxation in diabetic aorta. Am J Physiol 1988; 255: H825-H833.

169 Hattori Y, Kawasaki H, Abe K, Kanno M. Superoxide dismutase recovers altered endothelium-dependent relaxation in diabetic rat aorta. Am J Physiol 1991; 261: H1086-H1094.

170 Bucala $R$, Tracey KJ, Cerami A. Advanced glycosylation products quench nitric oxide and mediate defective endothelium-dependent vasodilatation in experimental diabetes. J Clin Invest 1991; 87: 432-8.

171 Radomski MW, Palmer RMJ, Moncada S. Glucocorticoids inhibit the expression of an inducible, but not the constitutive, nitric oxide synthase in vascular endothelial cells. Proc Natl Acad Sci USA 1990; 87: 10043-7.

172 Hibbs $J B$, Vavrin $Z$, Taintor RR. L-arginine is required for expression of the activated macrophage effector mechanism causing selective metabolic inhibition in targeted cells. J Immunol 1987; 138: 550-65.

173 Vallance $P$, Moncada $S$. Hyperdynamic circulation in cirrhosis: a role for nitric oxide? Lancet 1991; 337 : 776-8.

174 Julou-Schaeffer G, Gray GA, Fleming I, Schott C, Parrat $J R$, Stoclet JC. Loss of vascular responsiveness induced by endotoxin involves L-arginine pathway. Am J Physiol 1990; 259: H1038-H1043.

175 Petros A, Bennett D, Wallance P. Effect of nitric oxide synthase inhibitors on hypotension in patients with septic shock. Lancet 1991; 338: 1557-8. 